Islamic Republic of Iran: 2008 Article IV Consultation-Staff Report; Public Information Notice on the Executive Board Discussion; and Statement by the Executive Director for Islamic Republic of Iran

Under Article IV of the IMF's Articles of Agreement, the IMF holds bilateral discussions with members, usually every year. In the context of the 2008 Article IV consultation with Islamic Republic of Iran, the following documents have been released and are included in this package:

- $\quad$ The staff report for the 2008 Article IV consultation, prepared by a staff team of the IMF, following discussions that ended on May 11, 2008, with the officials of Islamic Republic of Iran on economic developments and policies. Based on information available at the time of these discussions, the staff report was completed on June 19, 2008. The views expressed in the staff report are those of the staff team and do not necessarily reflect the views of the Executive Board of the IMF.

- $\quad$ A Public Information Notice (PIN) summarizing the views of the Executive Board as expressed during its July 14, 2008 discussion of the staff report that concluded the Article IV consultation.

- $\quad$ A statement by the Executive Director for Islamic Republic of Iran.

The document listed below will be separately released.

\title{
Selected Issues Paper
}

The policy of publication of staff reports and other documents allows for the deletion of market-sensitive information.

Copies of this report are available to the public from

International Monetary Fund • Publication Services

$70019^{\text {th }}$ Street, N.W. $\bullet$ Washington, D.C. 20431

Telephone: (202) 623-7430 • Telefax: (202) 623-7201

E-mail: publications@imf.org • Internet: http://www.imf.org

Price: $\$ 18.00$ a copy

\section{International Monetary Fund Washington, D.C.}





\title{
INTERNATIONAL MONETARY FUND
}

\author{
ISLAMIC REPUBLIC OF IRAN
}

\section{Staff Report for the 2008 Article IV Consultation}

Prepared by the Staff Representatives for the 2008 Consultation with the Islamic Republic of Iran

Approved by Juan Carlos Di Tata and Scott Brown

June 19, 2008

- Discussions for the 2008 Article IV consultation were held in Tehran during April 28May 11, 2008. The mission comprised Mr. Kramarenko (head), Mr. Bonato, Ms. Zermeño, Mr. Zytek, Ms. Morsy, and Mr. Sakamoto (all MCD). Mr. Di Tata (MCD), and Messrs. Mojarrad and Monajemi (OED) participated in the policy discussions.

- The mission met with Central Bank Governor Mazaheri, Vice Minister of Economic Affairs and Finance Arabmazar, and other senior government officials, as well as representatives of the private sector.

- Iran maintains one exchange restriction and two multiple currency practices that are subject to approval under Article VIII, Sections 2 (a) and 3. The Fund approved the retention of the restriction through March 31,2008, and of the two multiple currency practices through March 10, 2009. The ministry of economy and finance has submitted to the cabinet a draft revision of the by-laws implementing the foreign direct investment law as part of the steps required to eliminate the exchange restriction (Annex I).

- Effective December 1, 2007, the exchange rate regime has been reclassified from a de facto fixed peg to a composite to a de facto crawling peg to a composite.

- The previous consultation was concluded on February 23, 2007. The staff report and $\mathrm{PIN}$ are available at http://www.imf.org/external/pubs/cat/longres.cfm?sk=20535.0. 
Executive Summary...... 4

I. Introduction. 5

II. Recent Developments 7

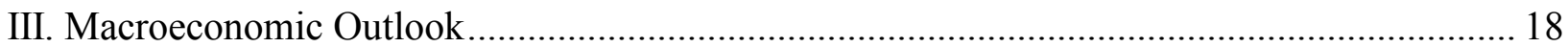

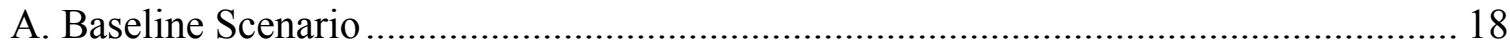

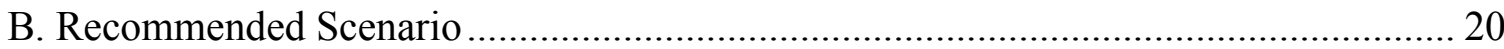

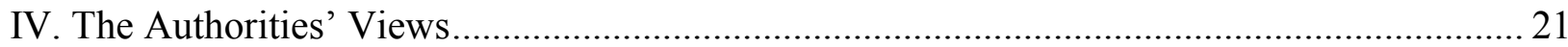

A. Policies to Reduce Inflation ............................................................................ 21

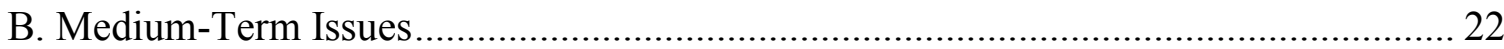

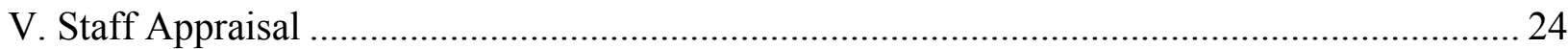

Box

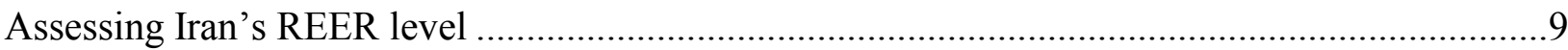

Text Tables

1. Selected Oil-Producing Countries: Hydrocarbon Sector Indicators, 2006 ....................5

2. Financial Soundness Indicators, 2003/04-2007/08 ....................................................... 16

Figures

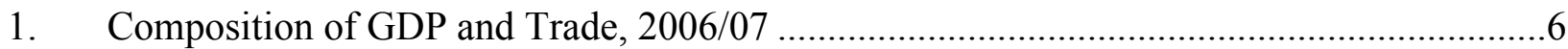

2. Growth, Unemployment, and Inflation, $1997 / 98-2008 / 09$.................................................

3. External Sector Developments, 2000/01-2008/09 ........................................................10

4. External Current Account Balance, 1997/98-2008/09 ......................................................11

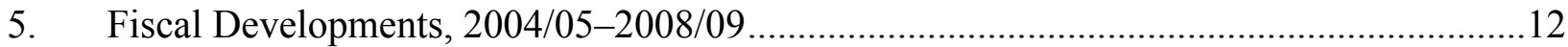

6. Monetary Developments, 2000/01-2008/09 ...................................................................14

7. Exchange Rate Developments, January 1, 2007- May 15, 2008 ..................................15

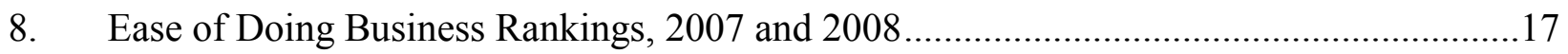

9. Medium-Term Scenarios, 2006/07-2013/14 _.................................................................19

Tables

1. Selected Macroeconomic Indicators, 2005/06-2008/09 ................................................27

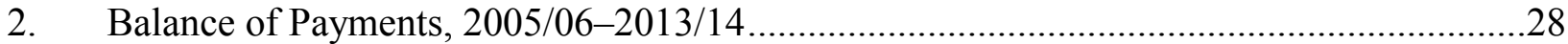

3. Consolidated Accounts of the Central Government and the Oil Stabilization Fund, 2005/06-2008/09 (In billions of rials). 
4. Consolidated Accounts of the Central Government and the Oil Stabilization

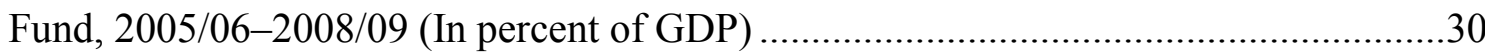

5. Central Bank Balance Sheet, 2005/06-2008/09 ……………………..............................31

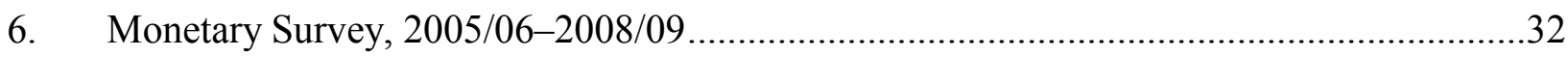

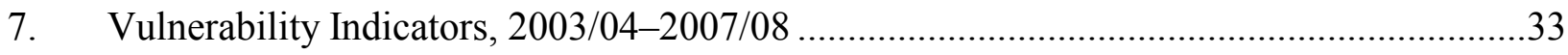

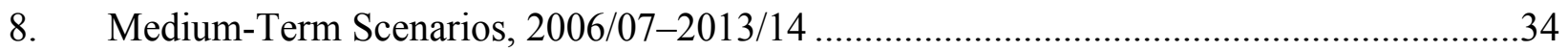




\section{Executive Summary}

\section{Background and outlook}

The economy is showing signs of overheating owing to high oil prices and a significant policy stimulus. Real GDP is estimated to have grown by 6.6 percent in 2007/08 (fiscal year ends on March 20), and gross official reserves reached $\$ 82$ billion (12 months of imports) by the end of the fiscal year. Inflation rose to 24.2 percent in April 2008, owing mainly to an expansionary credit policy and a significant, albeit recently reduced, fiscal stimulus. Unemployment has declined only slightly, against the background of an uneven pace of structural reforms.

The short-term growth outlook is good, but on current policies the staff envisages that inflation would remain at about 25 percent. Over the medium term, real GDP growth is projected to moderate to $4-5$ percent a year, in part reflecting stagnant oil production. The medium-term external position is very sensitive to the oil price assumptions.

\section{Authorities' views}

Reducing inflation. The authorities indicated that efforts to reduce inflation would focus on slowing expenditure growth and containing credit expansion through moral suasion on banks to reduce lending to low-priority sectors.

Strengthening the public finances. Fiscal reform plans under discussion include phasing out energy and nonenergy subsidies, streamlining the public administration, and strengthening revenue collection.

Stepping up structural reforms. Structural reform priorities include recapitalizing large stateowned banks and privatizing smaller banks, intensifying divestment efforts, aligning customs procedures with WTO standards, and improving the business climate.

\section{Staff recommendations}

- Macroeconomic policies need to be significantly tightened to lower inflation. In particular, there is a need to further reduce budgetary expenditure in 2008/09, and promptly increase banking rates of return and allow for nominal exchange rate appreciation.

- A decisive implementation of the envisaged fiscal reforms will help achieve further fiscal consolidation in the medium term, which is needed to reduce inflation and increase the economy's resilience in case of a decline in oil prices.

- Eliminating administrative controls, gearing the divestment process to private investors, reducing trade protection, and improving the business climate and the labor legislation will boost the economy's growth potential and employment creation. 


\section{INTRODUCTION}

1. Iran is endowed with vast hydrocarbon resources, but its capacity to increase hydrocarbon production is limited. In 2006, Iran had the second largest proven oil and gas reserves, and it was the fourth largest oil producer in the world. However, its oil production has remained virtually flat in recent years and will most likely stagnate in the medium term due to insufficient investment.

Text Table 1. Selected Oil-Producing Countries: Hydrocarbon Sector Indicators, 2006

\begin{tabular}{|c|c|c|c|c|c|c|}
\hline & \multicolumn{4}{|c|}{ Proven Reserves } & \multicolumn{2}{|l|}{ Production } \\
\hline & \multicolumn{2}{|c|}{ Oil } & \multicolumn{2}{|c|}{ Gas } & \multirow{2}{*}{$\begin{array}{c}\text { Oil } \\
\text { Millions of barrels per day }\end{array}$} & \multirow{2}{*}{$\begin{array}{c}\text { Gas } \\
\text { Billions of } \mathrm{m}^{3} \\
\end{array}$} \\
\hline & Billions of barrels & In percent of total & Trillions of $\mathrm{m}^{3}$ & In percent of total & & \\
\hline Iran & 137.5 & 11.4 & 28.3 & 15.5 & 4.4 & 105.0 \\
\hline Iraq & 115.0 & 9.5 & 3.2 & 1.7 & 2.0 & $\ldots$ \\
\hline Russian Federation & 79.5 & 6.6 & 47.7 & 26.3 & 9.8 & 612.1 \\
\hline Saudi Arabia & 264.3 & 21.9 & 7.1 & 3.9 & 10.9 & 73.7 \\
\hline
\end{tabular}

2. Iran has the largest economy in purchasing power parity terms in the Middle East and Central Asia (MCD) region, with a sizeable and diversified non-oil sector (Figure 1). Iran's economy is closely linked to intraregional trade and capital flows. On the one hand, Iran has benefited from rapid growth in the MCD region by increasing its regional non-oil exports. On the other, Iran's robust growth in recent years has had some positive impact on smaller Gulf Cooperation Council countries serving as transit points for Iranian imports and trade financing.

3. Fund policy advice has focused on measures to reduce inflation and structural reforms aimed at stimulating growth and employment creation. Consistent with Fund recommendations, in 2007/08 the authorities reduced the non-oil fiscal deficit, contained energy subsidies, improved revenue administration, and intensified their efforts to bring banking supervision closer to international standards. However, there has been no political consensus to implement other Fund recommendations such as tightening monetary policy and reducing government interference in resource allocation.

4. Against the background of strong demand pressures and an uneven pace of structural reforms, the consultation discussions focused on

- Policies to reduce inflation,

- Medium-term fiscal challenges, and

- $\quad$ Key growth-oriented structural reforms. 
Figure 1. Islamic Republic of Iran: Composition of GDP and Trade, 2006/07

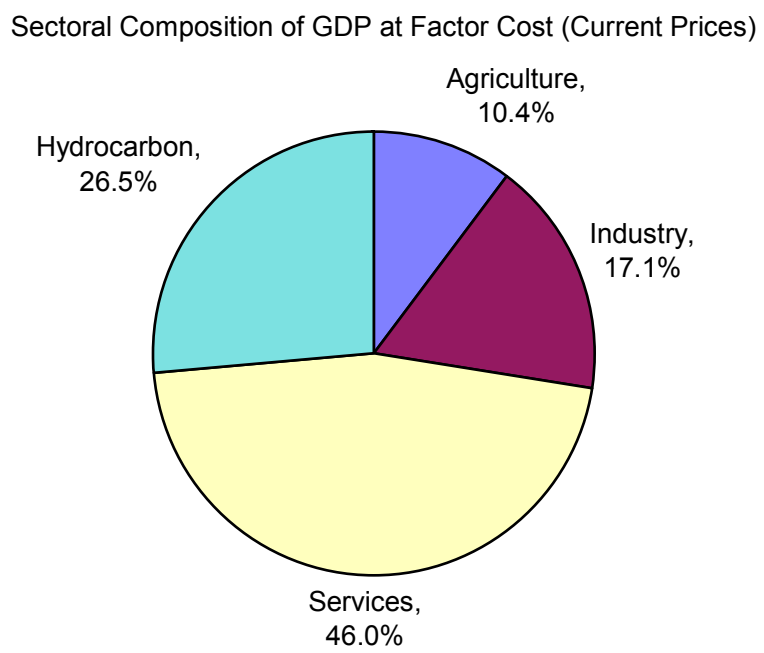

Share of Nonhydrocarbon Exports by Major Trading Partners

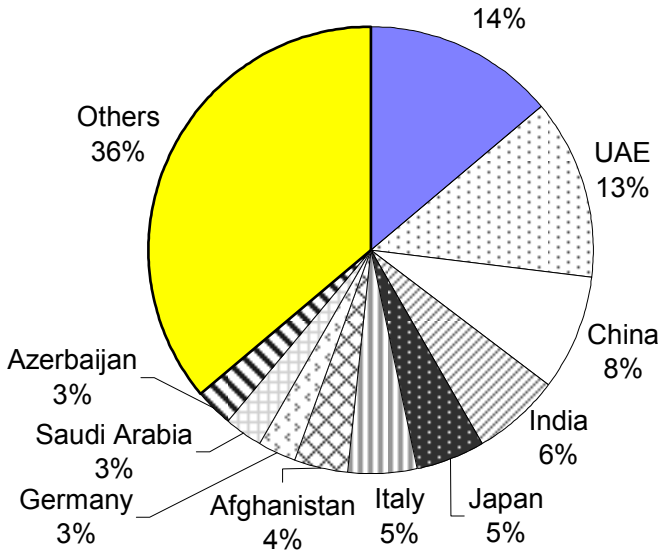

Share of Imports by Major Trading Partners

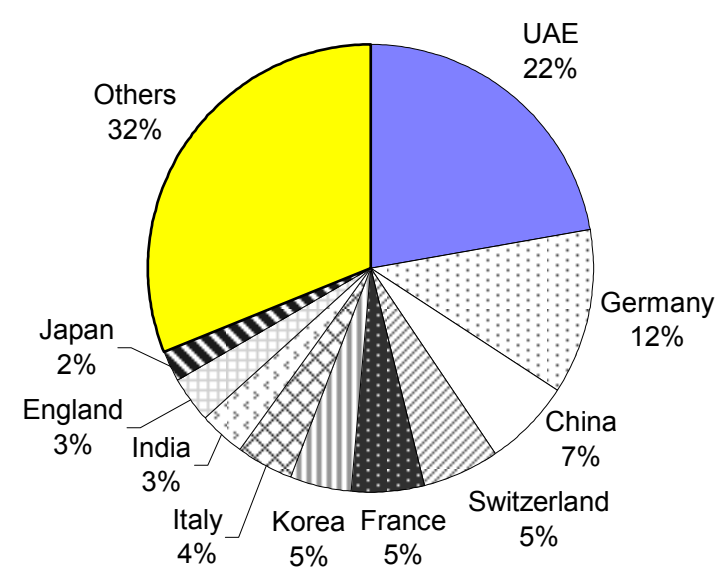

Sources: Iranian authorities; and Fund staff estimates. 


\section{RECENT DEVELOPMENTS}

5. Real GDP growth is estimated to have picked up to 6.6 percent in $2007 / 08$, from 6.2 percent in $\mathbf{2 0 0 6 / 0 7}$. Increased direct government support to priority sectors, scaled-up budgetary capital expenditure, and strong credit growth underpinned a robust and broadbased growth of the non-oil economy. Oil production, however, increased modestly, mainly owing to insufficient investment (Figure 2 and Table 1).

6. Intensified international pressures on Iran have negatively affected economic activity. UN and U.S. sanctions against certain Iranian institutions have created difficulties for trade financing and payments, discouraged foreign investment, and adversely affected the profitability of the targeted financial institutions.

7. Reducing unemployment has remained a challenge. The officially reported unemployment rate declined only marginally to 9.8 percent in the year to December 2007, in part reflecting a decline in the labor participation rate.

8. Inflation has been on the rise. Expansionary policies against the background of capacity constraints and to some extent rising import prices caused 12-month CPI inflation to increase to 24.2 percent in April 2008, from 16.8 percent in April 2007. CPI inflation excluding food and energy also increased to more than 20 percent in April 2008, suggesting strong underlying domestic demand pressures. ${ }^{1}$

\section{High oil prices supported a further strengthening of Iran's external position in}

2007/08. The current account surplus is estimated to have increased from 9.2 percent of GDP in 2006/07 to 10.2 percent in 2007/08 (Table 2). Notwithstanding large capital outflows ( $\$ 5.5$ billion in 2007/08), gross official reserves, including the Oil Stabilization Fund's (OSF) foreign assets, increased from $\$ 61$ billion (10 months of imports) at end-2006/07 to $\$ 82$ billion (almost 12 months of imports) at end-2007/08.

\footnotetext{
${ }^{1}$ Price controls contained the rise in CPI inflation: in 2007/08, the annual average increase in administered prices, accounting for about 12 percent of the CPI basket, was about 10 percent, compared with a 19 percent increase in the CPI.
} 

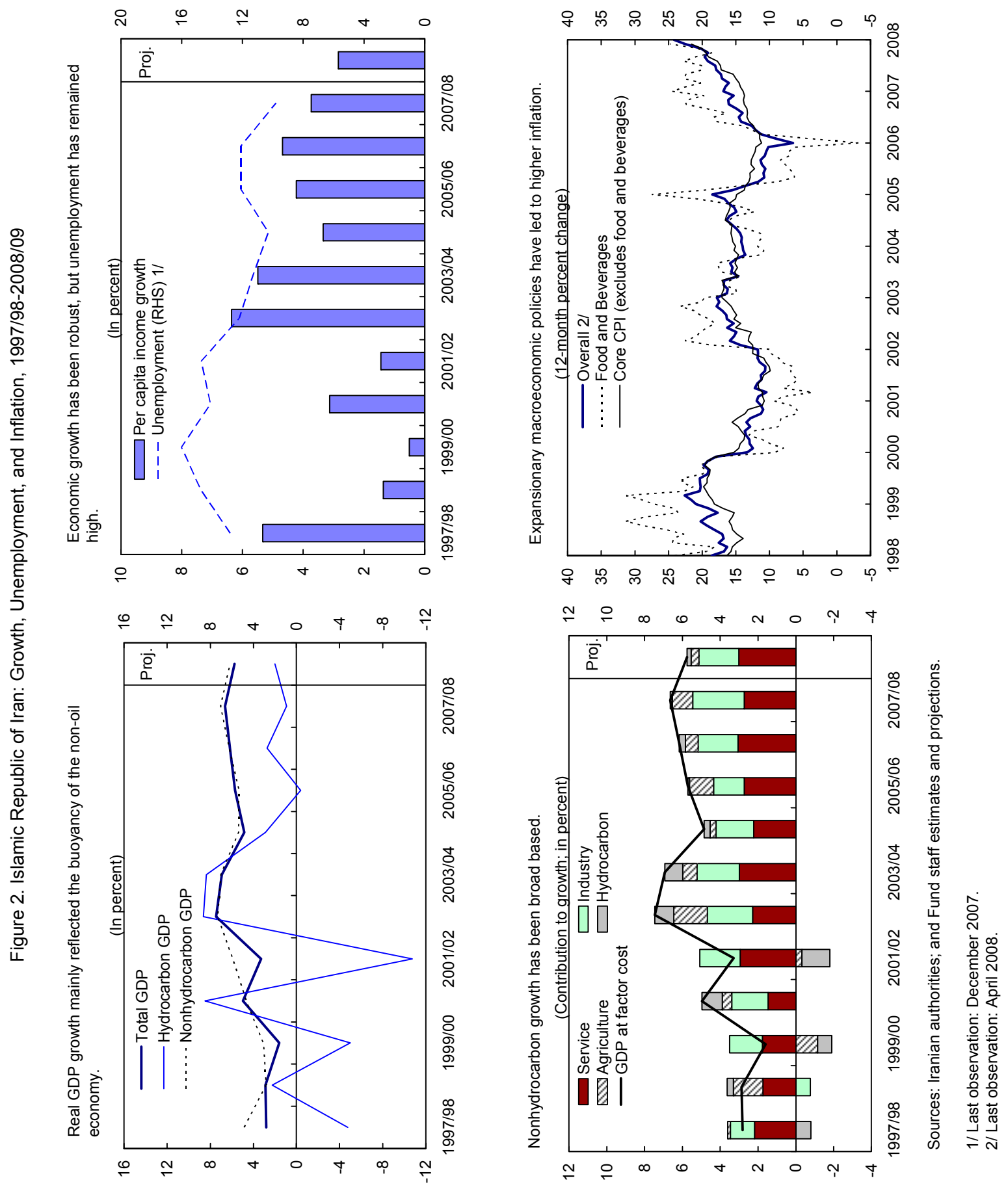
10. Despite recent rapid real effective exchange rate (REER) appreciation, the tradable non-oil sectors have performed relatively well (Figure 3 ). This could be explained by some initial currency undervaluation (Box), increased subsidies, and the rapid growth in trading partner countries. In addition, import-substituting manufacturing has benefited from relatively high import tariffs.

\section{Box. Assessing Iran's REER Level}

Staff estimates under the equilibrium real exchange rate approach (ERER) suggest that the REER was slightly undervalued in 2006/07. MCD countries' panel mean estimates suggest a 5 percent undervaluation. The panel covers the period 1986-2006 and includes the following explanatory variables: relative productivity, the fiscal balance, the cumulative current account balance, the terms of trade, and a trade openness indicator.

Some panel estimates for MCD oil-producing countries based on the macroeconomic balance approach show a significant exchange rate overvaluation, reflecting the fact that Iran has lower current account surpluses than many other oil-producing countries (Figure 4). However, it is reasonable to expect that Iran should generate lower current account surpluses than the macroeconomic balance approach would suggest because its oil wealth relative to its economy is larger than that of many other oil-producing countries. Since oil wealth is not included in the list of dependent variables, the existing estimates of current account norms for the panel of oilproducing countries are not suitable for Iran.

\section{Fiscal policy was tightened in $\mathbf{2 0 0 7 / 0 8}$ following a significant fiscal relaxation} during 2005/06-2006/07. The non-oil primary fiscal deficit rose from about 15 percent of GDP in 2004/05 to 21 percent in 2006/07, as the government increased transfers to households, subsidies, capital expenditure, and OSF lending (Figure 5 and Tables 3-4). ${ }^{2}$ The non-oil primary deficit, however, is estimated to have been reduced to 17 percent of GDP in 2007/08 through the rationing of subsidized gasoline, a reduction in nonwage current outlays, more moderate growth of capital expenditure, and a decline in OSF lending.

\section{The Central Bank of Iran's (CBI) ability to influence monetary policy decisions}

has been further curtailed. In 2007/08, the Monetary and Credit Council chaired by the CBI Governor was integrated into the government's supreme council for economic management and planning.

\footnotetext{
${ }^{2}$ The OSF was set up in 2000 to reduce the impact of oil price volatility on expenditure. Revenues in excess of budgeted amounts are deposited in the OSF. Up to 50 percent of OSF resources can be on-lent to domestic companies via banks. The remaining assets are deposited at the CBI, which manages them together with official reserves.
} 


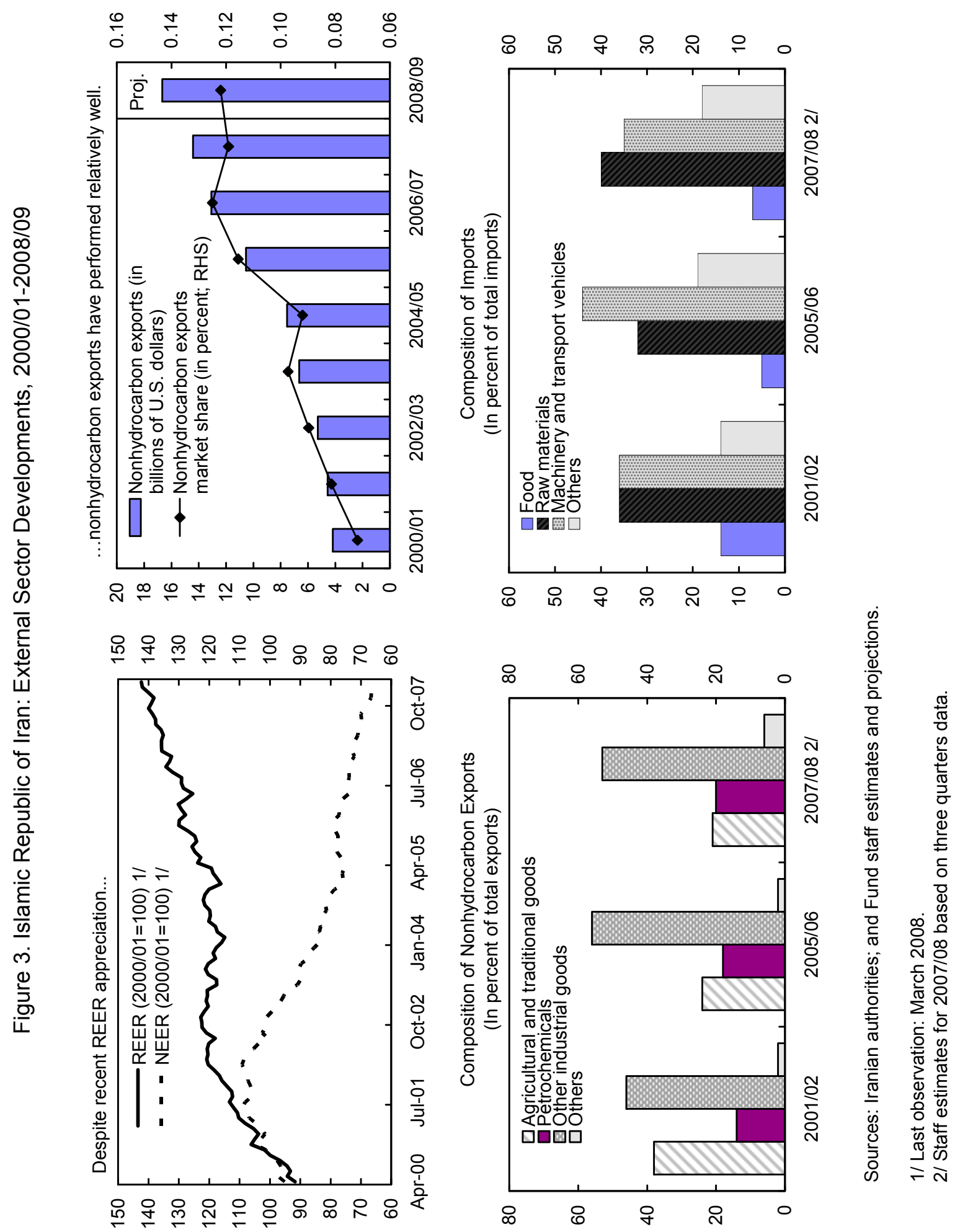




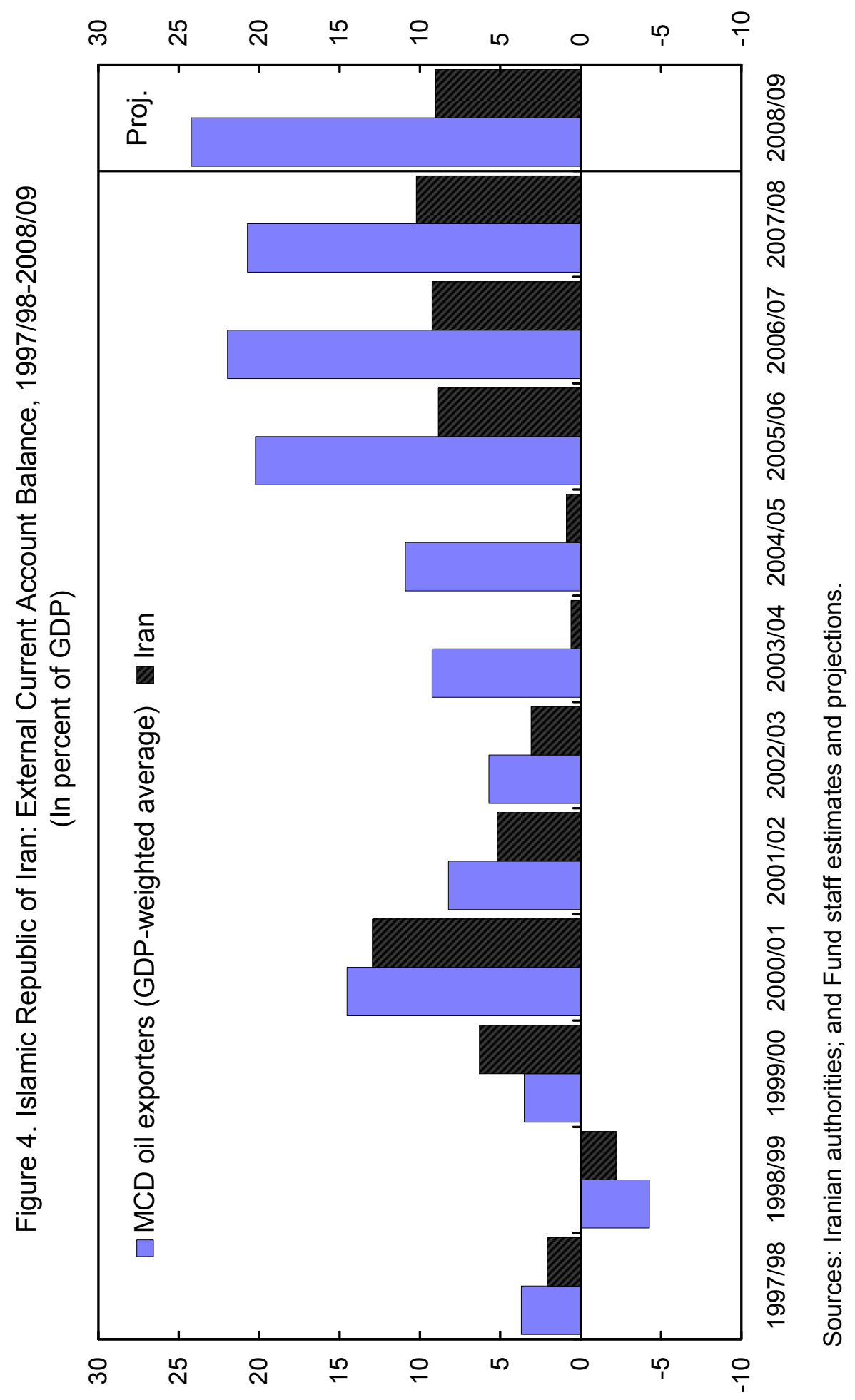




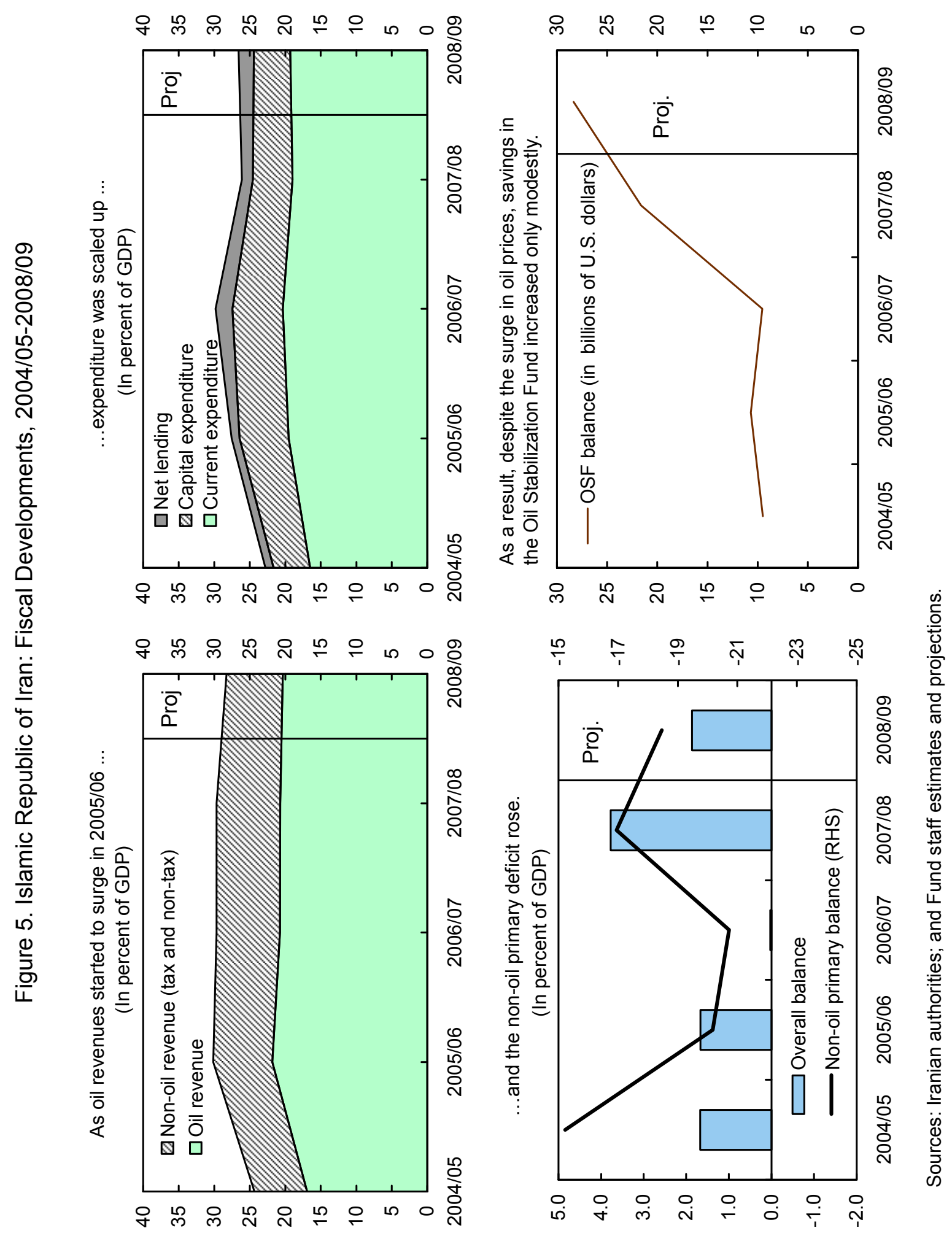




\section{Credit conditions were loosened in $2007 / 08$ and the rial continued to depreciate,} albeit at a slower pace. Faced with a reduction in budgetary expenditure and OSF lending, both private and state-owned enterprises intensified pressures for increased bank credit. The government's decision to reduce banking rates of return in mid-2007/08 exacerbated these pressures. ${ }^{3}$ To satisfy the growing demand for loans, state-owned commercial banks increasingly resorted to the CBI overdraft facility. As a result, the CBI's claims on banks became one of the main sources of money and credit growth (Figure 6 and Tables 5-6). A net redemption of Central Bank Participation Papers (CBPPs) and net purchases of foreign exchange were additional sources of liquidity growth. The authorities continued to target a slow rial depreciation vis-à-vis a basket of currencies, but the weight of the U.S. dollar in the basket was significantly reduced in late November 2007. As a result, the monthly depreciation of the nominal effective exchange rate (NEER) has recently declined (Figure 7).

\section{The deepening of financial intermediation has slowed down and dollarization has} increased recently. As real rates of return on domestic currency deposits became increasingly negative, the inflow of rial deposits into the domestic banking system began to slow down in 2007/08. At the same time, relative returns on foreign currency deposits became more attractive, which led to a significant rise in dollarization, albeit from a low base.

Notwithstanding the sharp increase in foreign currency deposits, the velocity of broad money (including foreign exchange deposits) remained unchanged in 2007/08, in contrast with a significant decline in previous years. The securities market has remained relatively modest.

\section{The legislative framework for banking supervision has continued to improve, but} some banking system vulnerabilities persist. The CBI approved new regulations on asset classification, provisioning, and banks' investment, and issued new guidelines on liquidity management and internal controls. While an anti-money laundering (AML) law became effective in January 2008, the law still contains deficiencies and its implementation will require the adoption of detailed regulations. In addition, Iran does not currently have in place an

\footnotetext{
${ }^{3}$ The rate of return on transaction contracts was reduced from 14 percent to 12 percent in state-owned banks and from 17 percent to 13 percent in private banks. The minimum expected rate of return on profit-and-loss-sharing (PLS) contracts was set at the same level. In April 2008, average lending rates for PLS contracts were estimated at about 16 percent for state-owned banks and at 22-23 percent for private banks, below the current inflation rate.
} 


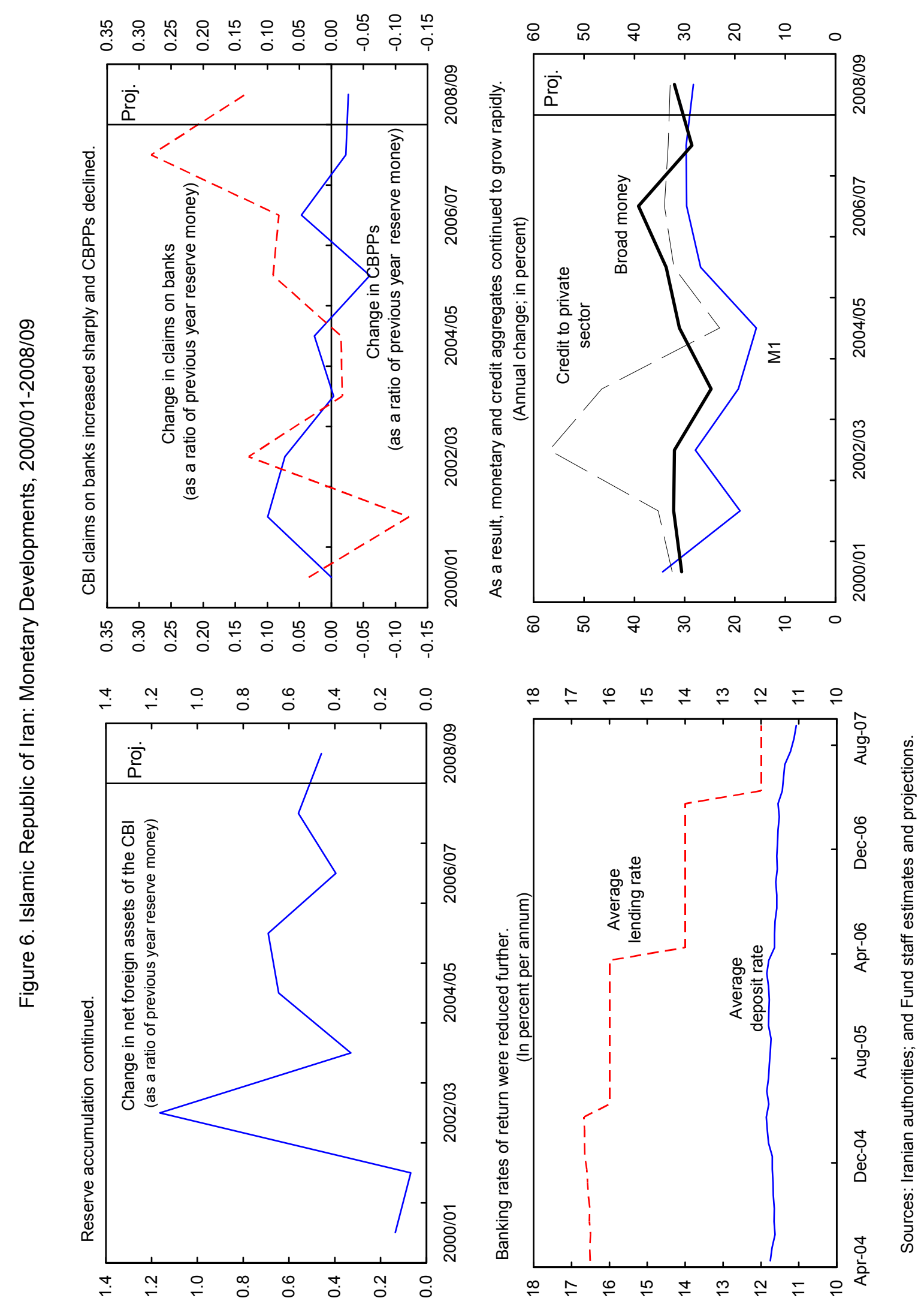




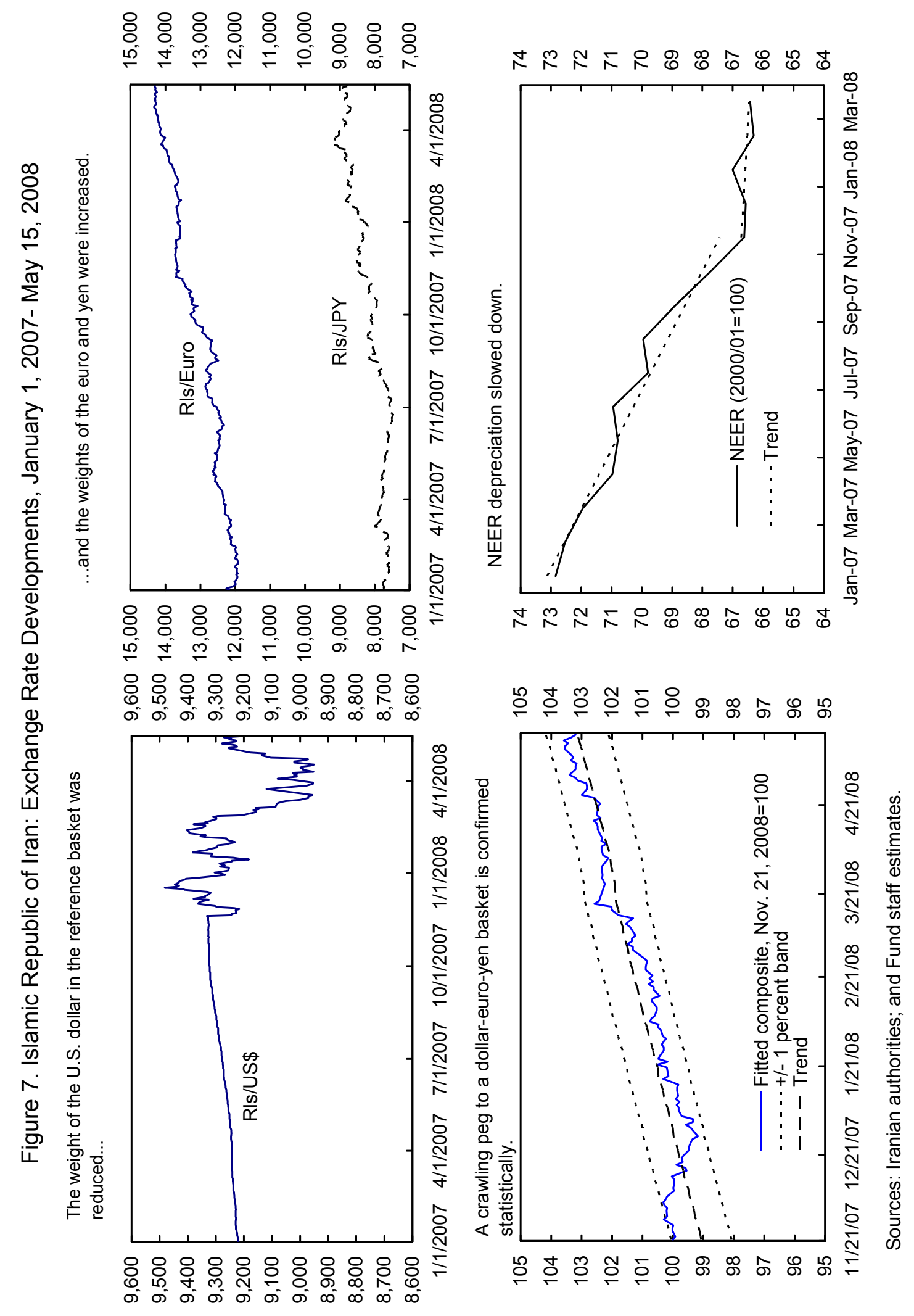


appropriate framework to counter the financing of terrorism (CFT). Regarding banking system indicators, the nonperforming loans ratio increased to about 16 percent at end-March 2007 (Table 7), and as mentioned earlier, the profitability of banks under sanctions has been adversely affected. Against this background, the authorities have recently recapitalized three state-owned banks by transforming OSF deposits funding loans to domestic enterprises (\$3 billion, about 1 percent of GDP) into government equity. However, some state-owned banks were still undercapitalized as of end-March 2008.

Text Table 2. Islamic Republic of Iran: Financial Soundness Indicators, 2003/04-2007/08 1/

\begin{tabular}{|c|c|c|c|c|c|}
\hline & $2003 / 04$ & $2004 / 05$ & $2005 / 06$ & $2006 / 07$ & $2007 / 08$ \\
\hline \multicolumn{6}{|l|}{ Banking sector indicators } \\
\hline Risk-weighted capital adequacy of banks (in percent) & 5.7 & 9.8 & 9.8 & 9.1 & $\ldots$ \\
\hline Ratio of nonperforming loans (in percent of total loans) & 7.4 & 7.7 & 9.9 & 15.7 & $\ldots$ \\
\hline Loan provisions (as a percentage of nonperforming loans) & 44.6 & 57.9 & 47.1 & $\ldots$ & $\ldots$ \\
\hline Deposits (in percent of GDP) & 46.2 & 48.3 & 55.0 & 63.6 & 63.621 \\
\hline Credit to the private sector (in percent of GDP) & 61.7 & 59.9 & 65.6 & 73.0 & 75.021 \\
\hline \multicolumn{6}{|l|}{ Market assessment/financial market indicators } \\
\hline Stock market price index (percent change; end-of-period) & 124.8 & 6.4 & -21.9 & 3.8 & 2.7 \\
\hline Stock market capitalization (in percent of GDP) & 27.9 & 27.6 & 19.2 & 19.3 & 17.221 \\
\hline
\end{tabular}

Sources: Iranian authorities; and Fund staff estimates.

$1 /$ The Iranian fiscal year ends on March 20.

2/ Based on Fund staff GDP estimates.

16. Progress on other structural reforms has been uneven. The increase in implicit energy subsidies was contained through the rationing of gasoline at higher prices. In addition, the preparatory technical and legislative work for implementing the VAT is close to completion, and tax collection agencies have been upgraded with new IT technology. Following the 2006 reinterpretation of Article 44 of the Constitution, the divestment process has gathered pace. However, given the lack of large private investors, many governmentowned entities were acquired through noncash or deferred settlements by quasi-public sector institutions. Furthermore, remaining weaknesses in the business climate, in particular in the areas of employing workers and dealing with licenses, constitute an obstacle to private sector development and employment creation (Figure 8). 
Figure 8. Islamic Republic of Iran: Ease of Doing Business Rankings, 2007 and 2008 Global Rank by Selected Countries, 2008

(Out of 178 countries)

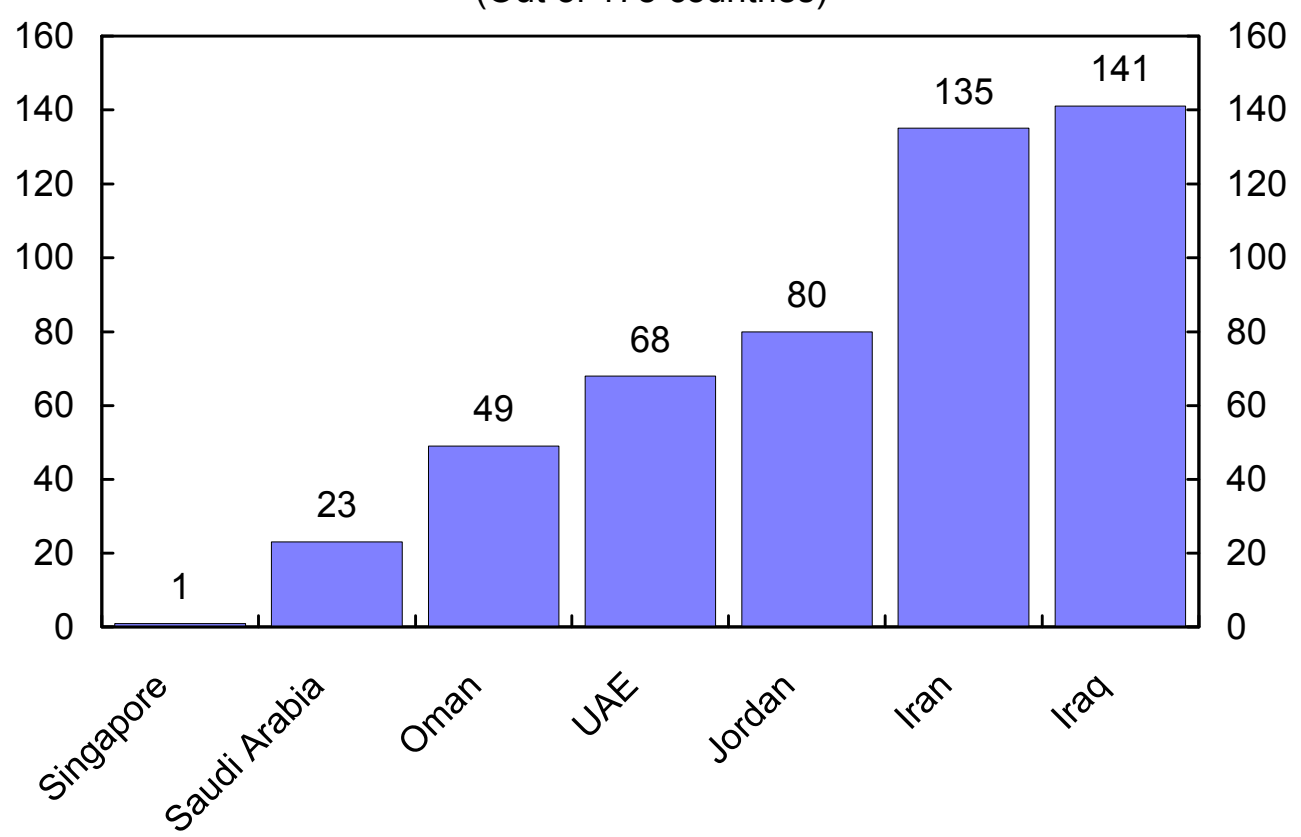

Iran: Rankings by Components, 2007 and 2008
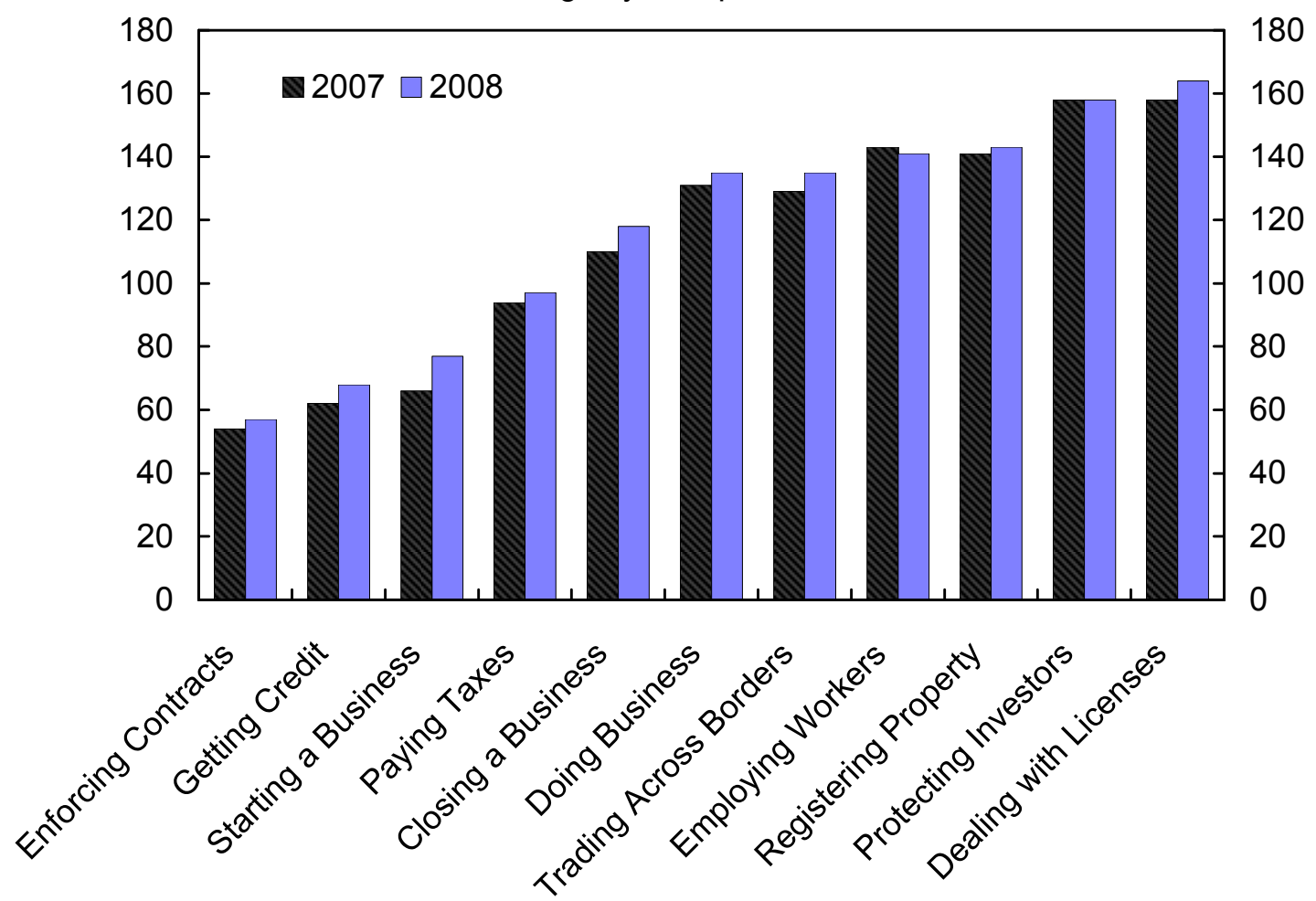

Source: Doing Business 2008, The World Bank Group. 


\section{MACROECONOMIC OUTLOOK}

\section{A. Baseline Scenario}

17. Iran's short-term growth and external prospects are good. Real GDP growth is projected to remain robust at 5.7 percent in 2008/09, despite a drought-related slowdown in agriculture. Notwithstanding buoyant domestic demand, the external current account surplus would be broadly unchanged at 9-10 percent of GDP in 2008/09, as oil prices are projected to remain well above their 2007/08 level.

18. Inflationary pressures are likely to persist in $\mathbf{2 0 0 8} / \mathbf{0 9}$. A projected widening of the non-oil primary fiscal deficit and increasingly negative real rates of return would fuel domestic demand growth. The staff believes that this, together with some exchange rate depreciation, would cause inflation to remain at about 25 percent in 2008/09. The balance of risks to this forecast is slanted to the upside, given a probable further reduction in regulated rates of return and a potential intensification of the financial disintermediation process.

19. Medium-term prospects are very sensitive to the oil price assumptions. The staff discussed with the authorities an illustrative medium-term baseline scenario based on the continuation of the government's current policies. This scenario assumes that prices for Iranian crude remain at \$85-\$90 per barrel, ${ }^{4}$ reforms advance unevenly, double-digit inflation persists, and oil production stagnates. Under such a scenario, Iran's growth potential would dwindle, a budget deficit most likely requiring CBI financing would emerge, and the economy's vulnerability to a possible fall in oil prices would increase. Specifically, real GDP growth is projected to decelerate to about $4 \frac{1}{2}$ percent a year by $2013 / 14$, while the external current account and budget positions would be in deficit by 2012/13, mainly reflecting flat oil export volumes (Figure 9 and Table 8).

\section{The sensitivity analysis demonstrates upside and downside risks to the baseline}

medium-term outlook. Should oil prices for Iranian crude stay above $\$ 110$ per barrel, in line with the current WEO forecast, Iran would continue to register significant current account surpluses and would accumulate about $\$ 190$ billion of gross official reserves by end-2013/14. However, if oil prices for Iranian crude fell to $\$ 75$ per barrel, the country would register current account deficits in the medium term, which would be unsustainable because of Iran's limited access to international financial markets (Figure 9).

\footnotetext{
${ }^{4}$ This oil price range is consistent with the Spring 2008 WEO assumptions circulated at the time of the consultation mission.
} 
Figure 9. Islamic Republic of Iran: Medium-Term Scenarios, 2006/07-2013/14
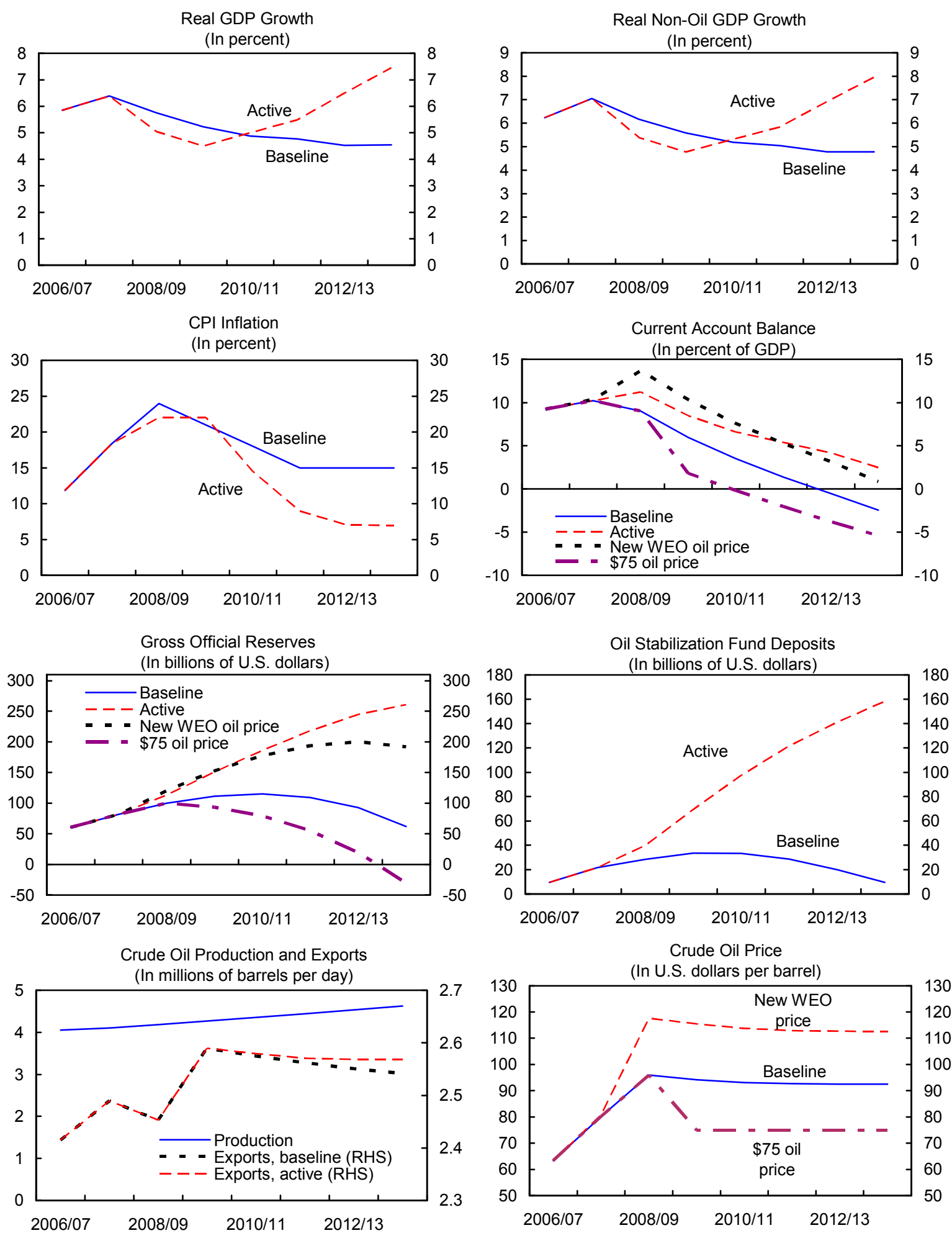

Sources: Iranian authorities; and Fund staff estimates and projections. 


\section{B. Recommended Scenario}

21. The staff has also prepared an illustrative active scenario for 2008/09. It assumes a reduction in the non-oil primary fiscal deficit and a tightening of monetary policy supported by greater exchange rate flexibility. These measures would help slow domestic demand growth and contain the annual increase in M1 to $18-20$ percent, ${ }^{5}$ which would contribute to reducing inflation to about 20 percent by end-2008/09. While the recommended adjustment would involve some output cost, delaying it beyond 2008/09 would entrench inflationary expectations, further increasing adjustment costs (Table 1).

\section{The medium-term outlook is significantly more favorable under the illustrative} active scenario because of further gains in macroeconomic stabilization and stepped-up structural reforms. This active scenario assumes further fiscal consolidation and the implementation of key structural reforms, including (i) the phasing out of energy subsidies; ${ }^{6}$ (ii) a further strengthening of revenue administration; (iii) the adoption of a rolling mediumterm fiscal framework and the integration of OSF expenditure with the central government budget; $^{7}$ (iv) the liberalization of the financial sector; and (v) measures to improve the business climate. As a result of these reforms, real GDP growth could increase to 7-8 percent a year, inflation would decline gradually to single digits, developmental and social budgetary spending would increase, and both the external current account and budget balances would remain in surplus, reducing the economy's vulnerability to a potential decline in oil prices (Figure 9 and Table 8).

\footnotetext{
${ }^{5}$ Econometric evidence identifies a close link between M1 and inflation; and the recent decline in local currency deposit growth is much more pronounced for time deposits than for sight deposits, suggesting that M1 is a better intermediate target than M2 (see Selected Issues Paper "Forecasting Inflation in the Islamic Republic of Iran").

${ }^{6}$ See Selected Issues Paper "Subsidies in the Islamic Republic of Iran."

${ }^{7}$ See Selected Issues Paper "Operations of the Oil Stabilization Fund."
} 


\section{The AUthorities' VieWs}

\section{A. Policies to Reduce Inflation}

23. The authorities expressed concern regarding the recent rise in inflation. They acknowledged that rapid domestic demand growth was an important factor driving inflation, but argued that higher import prices and international sanctions were significant cost-push factors. Against this background, the authorities stressed that they would seek to reduce inflation without undermining their short-term growth and employment objectives.

24. The authorities recognized that the fiscal relaxation envisaged for $\mathbf{2 0 0 8 / 0 9}$ would exacerbate domestic demand pressures. The approved 2008/09 budget is expected to result in an increase in the non-oil primary fiscal deficit from 17 percent of GDP in 2007/08 to 20 percent in 2008/09. Capital expenditure, transfers to the National Iranian Oil Company (NIOC), and OSF lending are budgeted to increase significantly. At the same time, non-oil revenue is expected to decline owing to a temporary revenue loss from the switch from the sales tax to the VAT and lower dividends from state-owned enterprises.

\section{The authorities indicated that the budget outcome in $2008 / 09$ was likely to be} stronger, which would help contain domestic demand growth. They thought that non-oil revenue would be above budget expectations on account of higher-than-expected inflation, while capital expenditure would be reduced by 30 percent based on a recent government circular. However, the authorities acknowledged that part of the savings from lower capital outlays might need to be reallocated to current outlays due to a very tight current expenditure envelope budgeted for 2008/09. All in all, based on the existing measures, the non-oil primary deficit could be limited to 18.5 percent of GDP in 2008/09. In addition, further expenditure reductions may be considered. The authorities also indicated that OSF foreign exchange lending would be spared from the expenditure cuts because it was used for import financing and had a limited impact on liquidity conditions.

\section{There are significant uncertainties regarding the direction of monetary policy.}

The government called for a further reduction in banking rates of return to support growth and employment creation. Following strong CBI opposition to this step, banking rates of return have remained on hold so far. At the same time, in recognition of the need to contain banks' overdrafts and credit growth, the government endorsed the CBI's proposal to intensify moral suasion on banks to redirect lending from retail trade and purchases of existing housing units to agriculture, industry, and construction. In addition, the outstanding stock of CBPPs will be reduced because it was deemed that CBI operations in the nascent interbank market would be more effective in mopping up excess liquidity. 
27. The authorities are evaluating whether the current exchange rate policy of slow depreciation strikes the appropriate balance between competitiveness and disinflation. They felt that some nominal depreciation would help slow down the ongoing rapid REER appreciation, at least in the short term. At the same time, the authorities acknowledged that this objective may conflict with the goal of containing liquidity growth and imported inflation, and indicated that they would undertake a comprehensive study on the benefits and risks of allowing a nominal appreciation of the rial. The authorities also characterized Iran's foreign exchange regime as a managed float (rather than a crawling peg) on the grounds that they adjust the exchange rate based on a set of economic fundamentals, and these adjustments are not automatic.

\section{B. Medium-Term Issues}

28. The authorities are working on the design of a number of important reforms that would improve the economy's growth potential. Priority will be given to developing the non-oil economy and increasing its overall efficiency. In addition, efforts will be made to attract more foreign investment to both the oil and non-oil sectors. The authorities also noted that, even in the absence of significant foreign investment in the oil sector, oil production could still be increased at a pace that would be sufficient to cover domestic demand and ensure adequate foreign exchange receipts.

\section{Fiscal policy}

29. The authorities are preparing far-reaching fiscal reforms. In particular, the government is finalizing a reform package aimed at phasing out explicit and implicit energy subsidies, as well as budgetary non-energy subsidies, and replacing them with targeted social assistance. Other planned fiscal reforms include a streamlining of the public administration to reduce the wage bill and a broadening of the tax base through revenue administration measures. The authorities would also examine the merits of moving from the current system of five-year fiscal planning to a rolling medium-term fiscal framework.

30. The authorities were broadly satisfied with the current institutional set-up of the OSF. They did not see a need for shifting OSF lending to the budget because most of this lending, in their opinion, was done on commercial or near-commercial terms and de facto replaced foreign credit lines to finance imports in the context of intensified sanctions. The authorities agreed that the transparency of the OSF could be further improved by publishing summary annual reports on a dedicated website.

\section{Financial sector}

31. The authorities will continue to support large state-owned banks and seek to privatize smaller banks. They plan to inject about $\$ 10$ billion of additional capital into the 
remaining under-capitalized state-owned banks by converting OSF deposits with these banks into equity. They have also slated two mid-sized banks for divestment and intend to re-invest the related proceeds to strengthen their capital. The authorities indicated that they would continue to regulate rates of return and sectoral credit allocation in the banking system in order to ensure that priority sectors have access to borrowing at rates of return consistent with their profitability.

32. The authorities noted that they would aim at enhancing the attractiveness of the domestic securities market. To this end, they are working on a new regulation on corporate governance for companies listed in the Tehran Stock Exchange and on amendments to the regulation on foreign portfolio investment.

33. The authorities indicated that they are committed to continue improving the AML/CFT legislation. They argued that an Intensified Anti-Economic Crime law had been in place for the past few years, that the CBI's AML/CFT regulations had been effectively addressing both money laundering and financing of terrorism activities, and that the passage of the new AML law had further strengthened the AML/CFT enforcement framework. The authorities noted that the concerns of international observers about the effectiveness of the AML/CFT legislation would be allayed through the implementation of the bylaws. To that end, they indicated that AML implementing regulations are being prepared, a Financial Intelligence Unit will be set up, and work on implementing CFT regulations is advancing. The authorities requested an IMF technical assistance (TA) mission to examine progress on developing the AML/CFT framework and provide further recommendations.

\section{Other structural issues}

34. The authorities intend to move forward with other structural reforms. The divestment program targets the transfer to the nongovernment sector of 80 percent of the government's shares in state-owned enterprises in most economic sectors by 2010 through cash and deferred payments. The authorities believe that the program will help improve the efficiency of enterprises, thereby stimulating growth and employment creation. They also see the divestment process as a means of promoting social justice by transferring shares to the lowest two deciles of the population at a 50-percent discount. In addition, the government is interested in cooperating with the World Bank on improving the business climate to facilitate private sector development and employment creation. Regarding trade reform, as part of its WTO accession efforts, the government has prepared a new customs act to align national customs procedures with WTO practices. However, at this time, there are no immediate plans to reduce import tariffs in highly protected sectors (including automobiles, furniture, and pharmaceuticals), with the possible exception of food products. 


\section{Staff Appraisal}

35. Iran's economic growth has been boosted by rising oil prices, the regional economic boom, and a strong policy stimulus. Real GDP growth averaged more than 6 percent a year during 2005/06-2007/08. Notwithstanding the strong domestic demand growth, external current account surpluses increased markedly and gross official reserves more than doubled during this period.

36. Policies aimed at stimulating domestic demand, however, are becoming less effective in supporting growth and employment creation. The recent rise in inflation suggests that the economy is overheated; and the persistence of high unemployment indicates that expansionary policies only have a temporary positive effect on employment creation against the background of uneven progress on structural reforms. Looking forward, it is crucial to slow domestic demand growth in order to lower inflation while stepping up structural reforms to increase the economy's growth potential and employment creation.

37. In the short term, a significant strengthening of the fiscal position is essential for containing inflationary pressures. While the authorities' intent to limit the increase in the non-oil primary fiscal deficit is a step in the right direction, an additional 2-3 percentage points of GDP in measures (e.g., a further reduction in energy subsidies) would be needed to significantly reduce the fiscal stimulus and limit the liquidity impact of fiscal operations.

38. There is an urgent need to tighten monetary policy by intensifying the use of market-based instruments. The rates of return on central bank facilities and the regulated banking rates of return should be raised promptly. These measures, followed by a gradual loosening of controls on banking rates of return and credit allocation, would help reduce the banks' use of the overdraft facility more effectively than moral suasion. Also, the authorities should reconsider the intended reduction in the stock of outstanding CBPPs, and use this sterilization instrument more proactively, given the uncertainties regarding the effectiveness of the nascent interbank market. It would also be important to develop a secondary market for CBPPs and promote their use as collateral in interbank transactions.

\section{Greater exchange rate flexibility would help pursue a more proactive monetary} policy. Discontinuing the depreciation of the rial vis-à-vis the basket of currencies and allowing for greater exchange rate flexibility would help curtail monetary growth and reduce imported inflation. The exchange rate will most likely appreciate under a more flexible exchange rate arrangement.

40. Providing the CBI with operational independence and establishing low inflation as its main objective would facilitate the implementation of monetary policy and help anchor expectations. In this regard, the authorities are strongly encouraged to resume their work on the draft of a new central bank law. 
41. Iran's medium-term prospects could be improved significantly. Over time, sustaining the economy's growth momentum and enhancing employment creation through subsidies and administrative measures would become increasingly difficult, even under relatively optimistic oil price assumptions. The medium-term outlook would be significantly more favorable with further gains in macroeconomic stabilization and a decisive effort to step up structural reforms.

42. While long-term fiscal sustainability is not a matter of concern, further mediumterm fiscal adjustment is justified by domestic and external considerations. Under the baseline scenario, the fiscal position would remain sustainable from a longer-term perspective, notwithstanding the projected emergence of a fiscal deficit by 2010/11. Nevertheless, it would be advisable to maintain fiscal surpluses in the medium term to support the disinflation process, reduce REER appreciation pressures, and strengthen the economy's resilience to a potential decline in oil prices in a context of limited access to foreign financing.

43. There is a need to mobilize political support for the adoption and vigorous implementation of the envisaged fiscal reforms. The medium-term adjustment effort should focus on phasing out energy subsidies, an area where the authorities have been doing valuable preparatory work. A gradual increase in energy prices to their international benchmark levels over a three-year period would mobilize substantial additional budget revenues, even assuming conservative oil prices by the end of the reform horizon. Efforts should also be intensified to strengthen non-oil revenue administration, in line with current plans. Part of these additional oil and non-oil revenues could be channeled to targeted social assistance and other productive spending, in line with the government's developmental objectives.

\section{Implementing a rolling medium-term fiscal framework would facilitate fiscal} policy implementation in the face of oil price volatility. Such a framework should (i) focus on a medium-term path for the non-oil primary deficit consistent with the authorities' inflation objective, developmental priorities, and targeted accumulation of precautionary OSF foreign assets; (ii) contain contingency plans for addressing any persistent deviations from the oil price forecasts and potential costs related to the vulnerabilities of the banking system; and (iii) allocate all oil revenues to the OSF and limit the use of its resources to financing the non-oil budget deficit. The authorities' intent to make more information about OSF operations available to the public is welcome.

\section{The deepening of financial intermediation would benefit from a further} strengthening of banks' financial position and the elimination of administrative controls. Recent efforts to improve banking system supervision, privatize two mid-sized banks, and recapitalize state-owned banks are steps in the right direction. These steps should be accompanied by a strengthening of the CBI's capacity to enforce prudential regulations. 
Furthermore, phasing out administrative controls on banks and giving them more freedom in selecting their clients and reflecting risk factors in the pricing of their products would strengthen the banking system, foster its growth, and reduce the need for additional recapitalizations in the future. To this end, strong political support will be necessary for the passage of new market-oriented commercial banking legislation and its effective implementation.

46. A prompt resolution of the remaining issues in the AML framework leading to its effective implementation and the establishment of a CFT framework will promote the integrity of Iran's financial system and improve the prospects for a closer integration of Iran into the global financial system. The authorities are encouraged to address the AML law's deficiencies and adopt implementing regulations, and to ensure that the CFT framework meets international standards. In this regard, the staff welcomes the authorities' intention to continue their cooperation with international organizations on these issues. To assist the authorities in this endeavor, a TA mission from the IMF Legal Department is prepared to visit Tehran in the near future.

47. Further real exchange rate appreciation pressures are unavoidable in the medium term, and related competitiveness concerns would be best addressed by (i) gearing the privatization program toward genuine private investors rather than quasipublic sector institutions; (ii) implementing a reduction in trade tariff and non-tariff barriers given the still high level of import protection; and (iii) continuing the dialogue with the World Bank on other reforms critical for growth and employment creation (e.g., the business environment and the labor market).

48. The staff encourages the authorities to take the necessary steps to eliminate the exchange restriction related to certain investments under the foreign investment law.

49. Data reporting to the Fund is broadly adequate for effective surveillance, but the remaining weaknesses need to be addressed. Recent improvements in data dissemination on the CBI website are welcome. However, there is a need to expand the coverage of the central government operations, and to improve the timeliness of financial sector vulnerability indicators.

50. It is recommended that the next Article IV consultation with the Islamic Republic of Iran be held on the standard 12-month cycle. 
Table 1. Islamic Republic of Iran: Selected Macroeconomic Indicators, 2005/06-2008/09 1/

\begin{tabular}{|c|c|c|c|c|c|}
\hline & \multirow[b]{3}{*}{$2005 / 06$} & \multirow[b]{3}{*}{$2006 / 07$} & \multirow{3}{*}{$\begin{array}{r}\text { Est. } \\
2007 / 08 \\
\end{array}$} & \multicolumn{2}{|c|}{ Proj. } \\
\hline & & & & Baseline & Active \\
\hline & & & & \multicolumn{2}{|c|}{$2008 / 09$} \\
\hline \multicolumn{6}{|l|}{ Oil and gas sector } \\
\hline Total oil and gas exports (in billions of U.S. dollars) & 53.8 & 62.5 & 76.9 & 91.0 & 93.1 \\
\hline Average oil export price (in U.S. dollars/barrel) & 50.6 & 57.0 & 72.2 & 86.3 & 86.3 \\
\hline \multirow[t]{2}{*}{ Crude oil production (in millions of barrels/day) } & 4.0 & 4.1 & 4.1 & 4.2 & 4.2 \\
\hline & \multicolumn{5}{|c|}{ (Annual percentage change; unless otherwise indicated) } \\
\hline \multicolumn{6}{|l|}{ National accounts } \\
\hline Nominal GDP at market prices (in billions of Iranian rials) & $1,697,305$ & $2,044,024$ & $2,649,118$ & $3,333,363$ & $3,261,548$ \\
\hline Nominal GDP (in billions of U.S. dollars) & 188.0 & 222.1 & 285.3 & 367.2 & 364.7 \\
\hline Real GDP at factor cost & 5.7 & 6.2 & 6.6 & 5.7 & 5.0 \\
\hline Real oil and gas GDP & 0.6 & 3.0 & 1.1 & 2.0 & 2.0 \\
\hline Real non-oil GDP & 6.4 & 6.6 & 7.3 & 6.2 & 5.4 \\
\hline CPI inflation (average) & 10.4 & 11.9 & 18.4 & 24.0 & 22.0 \\
\hline CPI inflation (end-of-period) & 10.2 & 15.3 & 22.5 & $24-28$ & 22.0 \\
\hline GDP deflator at factor cost & 15.3 & 13.8 & 21.8 & 19.0 & 17.2 \\
\hline Unemployment rate (in percent of labor force) & 12.1 & 12.1 & $\ldots$ & $\ldots$ & $\ldots$ \\
\hline \multicolumn{6}{|c|}{ (In percent of GDP at market prices; unless otherwise indicated) } \\
\hline \multicolumn{6}{|l|}{ Investment and savings } \\
\hline Investment & 33.2 & 32.6 & 31.7 & 31.2 & 29.5 \\
\hline Change in stocks & 5.8 & 6.2 & 6.7 & 6.3 & 6.4 \\
\hline Total fixed capital investment & 27.4 & 26.4 & 25.0 & 24.8 & 23.1 \\
\hline Public & 9.6 & 9.4 & 7.3 & 7.3 & 6.3 \\
\hline Private & 17.7 & 17.0 & 17.7 & 17.5 & 16.8 \\
\hline Gross national savings & 42.0 & 41.8 & 42.0 & 40.2 & 40.7 \\
\hline Public & 14.3 & 10.1 & 10.1 & 9.1 & 11.3 \\
\hline Private & 27.7 & 31.7 & 31.9 & 31.0 & 29.4 \\
\hline Savings/investment balance & 8.8 & 9.2 & 10.2 & 9.0 & 11.2 \\
\hline Public & 4.7 & 0.7 & 2.8 & 1.9 & 5.0 \\
\hline Private & 4.1 & 8.5 & 7.4 & 7.1 & 6.2 \\
\hline Budgetary operations & & & & & \\
\hline Revenue & 30.3 & 29.9 & 29.9 & 28.4 & 29.0 \\
\hline Oil & 21.8 & 20.8 & 20.7 & 20.3 & 21.0 \\
\hline Non-oil & 8.3 & 8.9 & 9.0 & 7.9 & 7.8 \\
\hline Expenditure and net lending, of which: & 28.6 & 29.8 & 26.1 & 26.6 & 24.0 \\
\hline Current & 19.5 & 20.3 & 19.0 & 19.3 & 17.7 \\
\hline Capital & 6.9 & 7.1 & 5.6 & 5.1 & 5.2 \\
\hline Balance (commitment basis) & 1.7 & 0.0 & 3.8 & 1.9 & 5.0 \\
\hline Balance (cash basis) & 4.7 & 0.7 & 2.8 & 1.9 & 5.0 \\
\hline Financing & -4.7 & -0.7 & -2.8 & -1.9 & -5.0 \\
\hline Domestic financing (banking sector) & -5.2 & -1.5 & -4.1 & -2.3 & -5.4 \\
\hline Domestic financing (nonbank, including privatization) & 0.5 & 0.8 & 1.3 & 0.3 & 0.3 \\
\hline External financing & 0.0 & 0.0 & 0.0 & 0.1 & 0.1 \\
\hline Non-oil balance (commitment basis) & -20.2 & -20.7 & -16.9 & -18.5 & -16.0 \\
\hline Non-oil primary balance (commitment basis) & -20.0 & -20.7 & -16.8 & -18.5 & -16.0 \\
\hline Non-oil balance (cash basis) & -17.1 & -20.0 & -17.9 & -18.5 & -16.0 \\
\hline Non-oil balance in percent of non-oil GDP (commitment basis) & -28.2 & -28.3 & -23.1 & -24.7 & -21.3 \\
\hline & & percentage & e; unless oth & se indicated) & \\
\hline Monetary sector $2 /$ & & & & & \\
\hline Net foreign assets & 44.9 & 16.9 & 25.7 & 17.2 & 27.7 \\
\hline Net domestic assets & -50.7 & 68.2 & 31.2 & 44.8 & 17.1 \\
\hline Credit to the private sector & 32.1 & 34.0 & 33.3 & 32.9 & 24.3 \\
\hline Narrow money (M1) & 26.8 & 29.6 & 29.7 & 28.2 & 18.9 \\
\hline Broad money (M3) & 33.6 & 39.2 & 28.6 & 32.0 & 22.0 \\
\hline Velocity of broad money (ratio of GDP to M3) & 2.0 & 1.7 & 1.7 & 1.6 & 1.7 \\
\hline & & ons of U.S. & ; unless othe & e indicated) & \\
\hline External sector & & & & & \\
\hline Exports of goods and services & 72.1 & 83.9 & 101.4 & 119.1 & 121.2 \\
\hline Imports of goods and services & -56.2 & -64.0 & -72.9 & -86.8 & -81.0 \\
\hline Current account balance & 16.6 & 20.5 & 29.2 & 33.1 & 41.0 \\
\hline In percent of GDP at market prices & 8.8 & 9.2 & 10.2 & 9.0 & 11.2 \\
\hline External public and publicly guaranteed debt & 24.8 & 23.2 & 26.1 & 23.1 & 23.1 \\
\hline Of which: short-term debt & 10.7 & 9.1 & 9.1 & 9.1 & 9.1 \\
\hline Gross official reserves & 46.8 & 60.5 & 81.7 & 100.2 & 113.0 \\
\hline In months of the following year's imports of goods and services & 9.0 & 10.2 & 11.5 & 12.6 & 15.4 \\
\hline Memorandum items: & & & & & \\
\hline Nominal effective exchange rate, $2000 / 01=100$ & 77.6 & 73.6 & 66.9 & $\ldots$ & $\ldots$ \\
\hline Real effective exchange rate, $2000 / 01=100$ & 126.7 & 131.6 & 136.3 & $\ldots$ & $\ldots$ \\
\hline Average exchange rate (Iranian rials per U.S. dollar) & 9,026 & 9,202 & 9,285 & $\ldots$ & $\ldots$ \\
\hline End-of-period exchange rate (Iranian rials per U.S. dollar) & 9,140 & 9,243 & 8,956 & $\ldots$ & $\ldots$ \\
\hline
\end{tabular}

Sources: Iranian authorities; and Fund staff estimates and projections.

$1 /$ The Iranian fiscal year ends on March 20.

2/ Monetary sector data for $2007 / 08$ are preliminary, with the exception of velocity, which is estimated. 


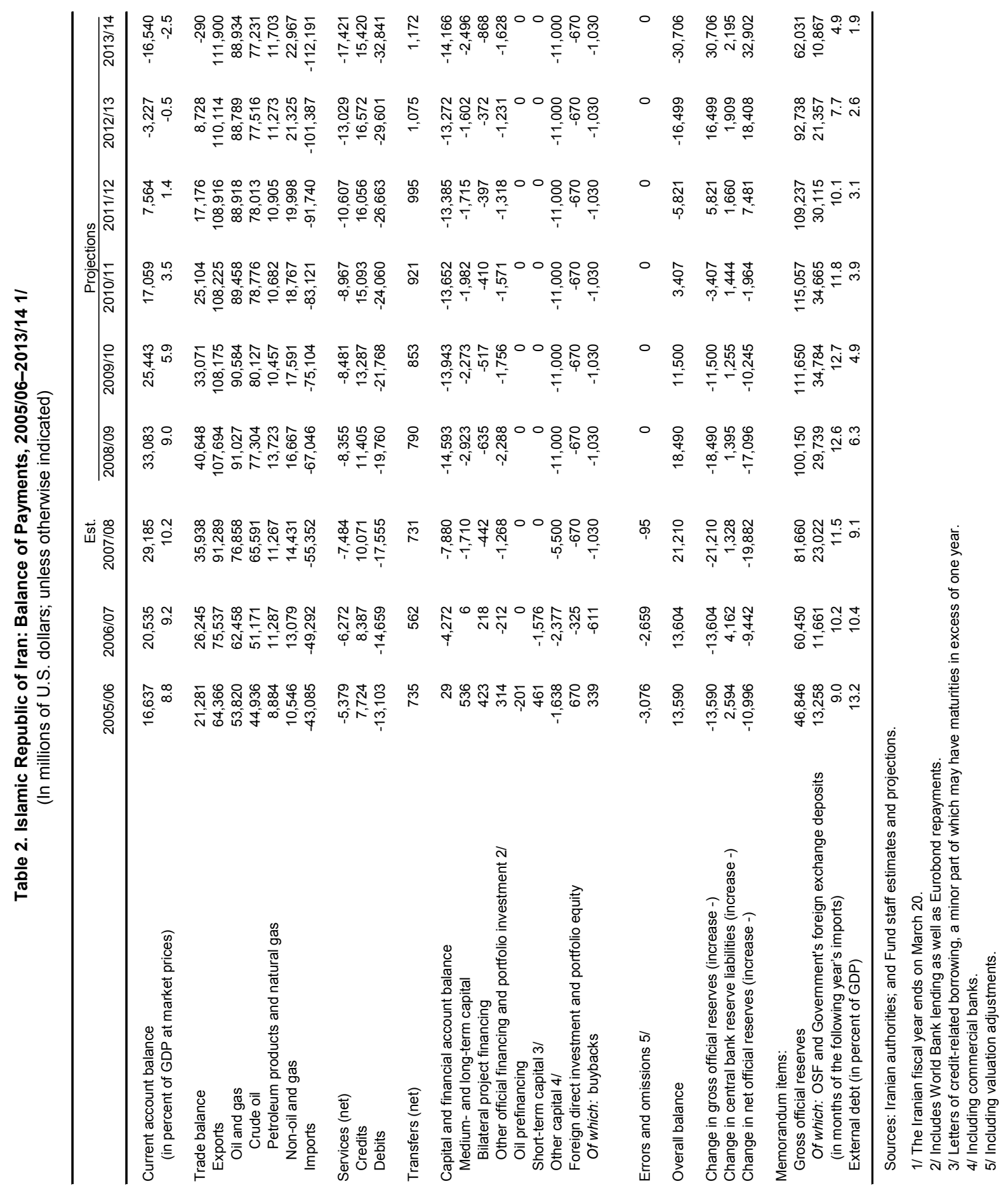


Table 3. Islamic Republic of Iran: Consolidated Accounts of the Central Government and the Oil Stabilization Fund, 2005/06-2008/09

(In billions of rials)

\begin{tabular}{|c|c|c|c|c|c|}
\hline \multirow[b]{2}{*}{ Revenues } & \multirow{2}{*}{$\frac{2005 / 06}{513,590}$} & \multirow{2}{*}{$\frac{2006 / 07}{610,262}$} & \multirow{2}{*}{$\begin{array}{r}\begin{array}{r}\text { Prel. } \\
2007 / 08\end{array} \\
791,199\end{array}$} & \multicolumn{2}{|c|}{$\begin{array}{r}\text { Budget } \\
2008 / 09 \\
\end{array}$} \\
\hline & & & & 948,745 & 947,841 \\
\hline Oil revenues & 370,739 & 424,150 & 548,833 & 697,502 & 677,648 \\
\hline Oil revenues to the budget & 325,150 & 392,761 & 424,059 & 576,205 & 549,549 \\
\hline Profit tax on NIOC 1/ & 31,869 & 26,134 & 29,237 & 36,700 & 36,700 \\
\hline Dividend transfers from NIOC & 28,682 & 23,521 & 32,425 & 58,721 & 58,721 \\
\hline Budget allocation & 186,342 & 181,881 & 173,519 & 298,866 & 298,866 \\
\hline Transfers from OSF & 78,256 & 161,225 & 188,879 & 181,918 & 155,261 \\
\hline $\begin{array}{l}\text { Oil revenues transferred to the OSF ( } \\
\text { the budget) }\end{array}$ & 45,589 & 31,389 & 124,774 & 121,297 & 128,100 \\
\hline Non-oil revenues to the budget & 140,775 & 182,387 & 237,815 & 246,427 & 264,704 \\
\hline Tax & 102,705 & 125,487 & 162,501 & 180,455 & 193,558 \\
\hline Direct tax & 52,161 & 71,557 & 97,028 & 112,196 & 120,078 \\
\hline Indirect tax & 14,590 & 14,123 & 16,654 & 14,716 & 15,670 \\
\hline Customs duties & 35,954 & 39,806 & 48,819 & 53,543 & 57,810 \\
\hline Nontax & 38,070 & 56,900 & 75,314 & 65,972 & 71,146 \\
\hline Non-oil revenues to the OSF & 2,076 & 3,725 & 4,551 & 4,816 & 5,489 \\
\hline Expenditure & 485,284 & 609,730 & 691,225 & 923,015 & 885,739 \\
\hline Central government expenditures & 448,523 & 561,354 & 650,936 & 850,395 & 813,119 \\
\hline Current expenditures & 330,884 & 415,793 & 503,220 & 607,871 & 643,352 \\
\hline Compensation of employees & 153,220 & 133,584 & 151,583 & 160,678 & 190,736 \\
\hline Interest payments & 4,264 & 4,743 & 7,370 & 558 & 5,982 \\
\hline Subsidies & 53,192 & 60,600 & $\ldots$ & 61,717 & 61,717 \\
\hline Goods and services & 41,637 & 32,263 & $\ldots$ & 48,742 & 48,742 \\
\hline Grants & 2,168 & 43,857 & $\ldots$ & 49,505 & 49,505 \\
\hline Social benefits & 7,142 & 69,959 & $\ldots$ & 110,947 & 110,947 \\
\hline Gasoline imports & 35,748 & 43,959 & 33,820 & 30,000 & 30,000 \\
\hline Other & 33,513 & 26,828 & 81,885 & 145,724 & 145,724 \\
\hline Capital expenditures & 117,639 & 145,561 & 147,716 & 242,524 & 169,767 \\
\hline OSF expenditures & 36,762 & 48,376 & 40,289 & 72,620 & 72,620 \\
\hline Domestic on-lending & 19,370 & 48,376 & 40,289 & 72,620 & 72,620 \\
\hline Other & 17,392 & 0 & 0 & 0 & 0 \\
\hline Overall balance (commitment basis) & 28,306 & 532 & 99,974 & 25,730 & 62,101 \\
\hline Overall balance (cash basis) & 79,827 & 14,799 & 74,062 & 25,730 & 62,101 \\
\hline Non-oil balance (commitment basis) & $-342,433$ & $-423,618$ & $-448,859$ & $-671,772$ & $-615,547$ \\
\hline Non-oil balance (cash basis) & $-290,912$ & $-409,351$ & $-474,771$ & $-671,772$ & $-615,547$ \\
\hline Financing & $-79,827$ & $-14,799$ & $-74,062$ & $-25,730$ & $-62,101$ \\
\hline Foreign financing & 626 & 673 & 1,233 & 3,583 & 3,583 \\
\hline Domestic financing & $-80,453$ & $-15,472$ & $-75,295$ & $-29,313$ & $-65,684$ \\
\hline Banking system & $-88,217$ & $-30,927$ & $-109,136$ & $-63,258$ & $-75,629$ \\
\hline Central bank & $-64,263$ & $-34,913$ & $-126,017$ & $-63,258$ & $-75,629$ \\
\hline Commercial banks & $-23,955$ & 3,987 & 16,881 & 0 & 0 \\
\hline Other domestic, including privatization & 7,765 & 15,455 & 33,841 & 33,945 & 9,945 \\
\hline
\end{tabular}

Sources: Iranian authorities; and Fund staff estimates and projections.

1/ National Iranian Oil Corporation. 
Table 4. Islamic Republic of Iran: Consolidated Accounts of the Central Government and the Oil Stabilization Fund, 2005/06-2008/09

\begin{tabular}{|c|c|c|c|c|c|}
\hline & $2005 / 06$ & $2006 / 07$ & $\begin{array}{r}\text { Est. } \\
2007 / 08 \\
\end{array}$ & $\frac{\text { Budget }}{200}$ & Proj. \\
\hline & \multicolumn{5}{|c|}{ (In percent of GDP) } \\
\hline Revenues & 30.3 & 29.9 & 29.9 & 28.5 & 28.4 \\
\hline Oil revenues & 21.8 & 20.8 & 20.7 & 20.9 & 20.3 \\
\hline Oil revenues to the budget & 19.2 & 19.2 & 16.0 & 17.3 & 16.5 \\
\hline Profit tax on NIOC & 1.9 & 1.3 & 1.1 & 1.1 & 1.1 \\
\hline Dividend transfers from $\mathrm{NIOC}$ & 1.7 & 1.2 & 1.2 & 1.8 & 1.8 \\
\hline Budget allocation & 11.0 & 8.9 & 6.6 & 9.0 & 9.0 \\
\hline Transfers from OSF & 4.6 & 7.9 & 7.1 & 5.5 & 4.7 \\
\hline Oil revenues transferred to the OSF & 2.7 & 1.5 & 4.7 & 3.6 & 3.8 \\
\hline Non-oil revenues to the budget & 8.3 & 8.9 & 9.0 & 7.4 & 7.9 \\
\hline Tax & 6.1 & 6.1 & 6.1 & 5.4 & 5.8 \\
\hline Direct tax & 3.1 & 3.5 & 3.7 & 3.4 & 3.6 \\
\hline Indirect tax & 0.9 & 0.7 & 0.6 & 0.4 & 0.5 \\
\hline Customs duties & 2.1 & 1.9 & 1.8 & 1.6 & 1.7 \\
\hline Nontax & 2.2 & 2.8 & 2.8 & 2.0 & 2.1 \\
\hline Non-oil revenues to the OSF & 0.1 & 0.2 & 0.2 & 0.1 & 0.2 \\
\hline Expenditure & 28.6 & 29.8 & 26.1 & 27.7 & 26.6 \\
\hline Central government expenditures & 26.4 & 27.5 & 24.6 & 25.5 & 24.4 \\
\hline Current expenditures & 19.5 & 20.3 & 19.0 & 18.2 & 19.3 \\
\hline Compensation of employees & 9.0 & 6.5 & 5.7 & 4.8 & 5.7 \\
\hline Interest payments & 0.3 & 0.2 & $\ldots$ & 0.0 & 0.2 \\
\hline Subsidies & 3.1 & 3.0 & $\ldots$ & 1.9 & 1.9 \\
\hline Goods and services & 2.5 & 1.6 & $\ldots$ & 1.5 & 1.5 \\
\hline Grants & 0.1 & 2.1 & $\ldots$ & 1.5 & 1.5 \\
\hline Social benefits & 0.4 & 3.4 & $\ldots$ & 3.3 & 3.3 \\
\hline Gasoline imports & 2.1 & 2.2 & 1.3 & 0.9 & 0.9 \\
\hline Other & 2.0 & 1.3 & 3.1 & 4.4 & 4.4 \\
\hline Capital expenditures & 6.9 & 7.1 & 5.6 & 7.3 & 5.1 \\
\hline OSF expenditures & 2.2 & 2.4 & 1.5 & 2.2 & 2.2 \\
\hline Domestic on-lending & 1.1 & 2.4 & 1.5 & 2.2 & 2.2 \\
\hline Other & 1.0 & 0.0 & 0.0 & 0.0 & 0.0 \\
\hline Overall balance (commitment basis) & 1.7 & 0.0 & 3.8 & 0.8 & 1.9 \\
\hline Overall balance (cash basis) & 4.7 & 0.7 & 2.8 & 0.8 & 1.9 \\
\hline Non-oil balance (commitment basis) & -20.2 & -20.7 & -16.9 & -20.2 & -18.5 \\
\hline Non-oil balance (cash basis) & -17.1 & -20.0 & -17.9 & -20.2 & -18.5 \\
\hline Non-oil primary balance (commitment basis) & -20.0 & -20.7 & -16.8 & -20.3 & -18.5 \\
\hline \multirow[t]{2}{*}{ Non-oil primary balance (cash basis) } & -17.0 & -20.0 & -17.8 & -20.3 & -18.5 \\
\hline & \multicolumn{5}{|c|}{ (In percent of non-oil GDP) } \\
\hline Non-oil revenues & 11.7 & 12.4 & 12.5 & 10.1 & 10.8 \\
\hline Expenditure & 39.9 & 40.7 & 35.6 & 37.0 & 35.6 \\
\hline \multirow[t]{2}{*}{ Non-oil budget balance } & -28.2 & -28.3 & -23.1 & -27.0 & -24.7 \\
\hline & \multicolumn{5}{|c|}{ (In percent of GDP) } \\
\hline \multicolumn{6}{|l|}{ Memorandum items: } \\
\hline Net public debt & 7.3 & 4.2 & 0.1 & 0.0 & -1.8 \\
\hline Gross public debt & 23.7 & 19.7 & 17.2 & 13.7 & 13.9 \\
\hline Government financial assets & 16.4 & 15.5 & 17.1 & 13.6 & 15.7 \\
\hline
\end{tabular}

Sources: Iranian authorities; and Fund staff estimates and projections. 
Table 5. Islamic Republic of Iran: Central Bank Balance Sheet, 2005/06-2008/09

(In billions of rials; unless otherwise indicated)

\begin{tabular}{|c|c|c|c|c|}
\hline & $2005 / 06$ & $2006 / 07$ & $\begin{array}{r}\text { Prel. } \\
2007 / 08\end{array}$ & $\begin{array}{r}\text { Proj. } \\
2008 / 09\end{array}$ \\
\hline Net foreign assets (NFA) & 389,080 & 480,740 & 643,872 & 818,610 \\
\hline In millions of U.S. dollars & 42,569 & 52,011 & 71,893 & 88,989 \\
\hline Foreign assets & 428,172 & 558,740 & 731,346 & 921,288 \\
\hline In millions of U.S. dollars & 46,846 & 60,450 & 81,660 & 100,150 \\
\hline Foreign liabilities $1 /$ & 39,092 & 78,000 & 87,474 & 102,678 \\
\hline In millions of U.S. dollars & 4,277 & 8,439 & 9,767 & 11,162 \\
\hline Net domestic assets (NDA) & $-139,345$ & $-163,596$ & $-245,868$ & $-295,392$ \\
\hline Net domestic credit & $-65,320$ & $-75,882$ & $-113,164$ & $-130,953$ \\
\hline Central government, net & $-123,193$ & $-158,107$ & $-284,124$ & $-359,753$ \\
\hline Claims & 101,255 & 87,450 & 81,257 & 76,365 \\
\hline Deposits & 224,448 & 245,557 & 365,381 & 436,118 \\
\hline Claims on banks & 35,916 & 54,887 & 136,972 & 188,015 \\
\hline Claims on nonfinancial public enterprises (NFPEs) & 21,957 & 27,337 & 33,988 & 40,785 \\
\hline Other items net, excluding central bank participation papers (CBPPs) & $-74,025$ & $-87,714$ & $-132,703$ & $-164,439$ \\
\hline Base money & 231,830 & 292,064 & 380,827 & 516,013 \\
\hline Currency & 55,681 & 67,489 & 88,047 & 123,996 \\
\hline Currency in circulation & 50,676 & 61,452 & 79,909 & 112,535 \\
\hline Cash in vaults & 5,005 & 6,038 & 8,138 & 11,460 \\
\hline Reserves & 164,860 & 212,486 & 275,299 & 361,624 \\
\hline Required reserves & 128,002 & 184,828 & 235,841 & 307,589 \\
\hline Excess reserves & 36,858 & 27,658 & 39,458 & 54,035 \\
\hline Deposits of NFPE and municipalities & 11,289 & 12,089 & 17,481 & 30,393 \\
\hline Other liabilities & 17,905 & 25,079 & 17,177 & 7,205 \\
\hline CBPPs & 10,769 & 21,566 & 14,972 & 5,000 \\
\hline Foreign currency deposits of NFPEs and municipalities & 7,136 & 3,514 & 2,205 & 2,205 \\
\hline \multicolumn{5}{|l|}{ Memorandum items: } \\
\hline \multicolumn{5}{|l|}{ End-period change (in percent of base money) } \\
\hline Base money & 46.5 & 26.0 & 30.4 & 35.5 \\
\hline NFA & 69.0 & 39.5 & 55.9 & 45.9 \\
\hline NDA (net of other liabilities) & -22.5 & -13.6 & -25.5 & -10.4 \\
\hline
\end{tabular}

Sources: Central Bank of Iran; and Fund staff estimates and projections.

$1 /$ Includes some liabilities in foreign currency to residents. 
Table 6. Islamic Republic of Iran: Monetary Survey, 2005/06-2008/09 1/

(In billions of rials; unless otherwise indicated)

\begin{tabular}{|c|c|c|c|c|}
\hline & $2005 / 06$ & $2006 / 07$ & $\begin{array}{r}\text { Prel. } \\
2007 / 08\end{array}$ & $\begin{array}{r}\text { Proj } \\
2008 / 09\end{array}$ \\
\hline Net foreign assets (NFA) & 561,943 & 656,772 & 825,374 & 967,172 \\
\hline In millions of U.S. dollars & 61,482 & 71,056 & 92,159 & 105,138 \\
\hline Foreign assets & 694,148 & 820,599 & $1,029,285$ & $1,227,313$ \\
\hline In millions of U.S. dollars & 75,946 & 88,781 & 114,927 & 133,417 \\
\hline Foreign assets of the Central Bank of Iran (CBI) & 428,172 & 558,740 & 731,346 & 921,288 \\
\hline In millions of U.S. dollars & 46,846 & 60,450 & 81,660 & 100,150 \\
\hline Foreign assets of banks & 265,976 & 261,859 & 297,939 & 306,025 \\
\hline In millions of U.S. dollars & 29,100 & 28,331 & 33,267 & 33,267 \\
\hline Foreign liabilities 2/ & 132,206 & 163,828 & 203,911 & 260,141 \\
\hline In millions of U.S. dollars & 14,465 & 17,725 & 22,768 & 28,279 \\
\hline Net domestic assets (NDA) & 432,137 & 726,828 & 953,306 & $1,380,686$ \\
\hline Net domestic credit & $1,070,839$ & $1,414,560$ & $1,797,546$ & $2,382,410$ \\
\hline Net credit to government & $-141,761$ & $-172,688$ & $-281,824$ & $-357,453$ \\
\hline Claims on nonfinancial public enterprises (NFPEs) & 99,813 & 95,951 & 91,983 & 98,780 \\
\hline Claims on private sector $3 /$ & $1,112,786$ & $1,491,297$ & $1,987,387$ & $2,641,083$ \\
\hline Of which: Foreign currency claims 3/ & 247,471 & 265,096 & 323,661 & 406,037 \\
\hline Other items, net, excluding CBPPs & $-638,702$ & $-687,732$ & $-844,240$ & $-1,001,724$ \\
\hline Broad money (M3) & 994,080 & $1,383,600$ & $1,778,680$ & $2,347,858$ \\
\hline M2 & 932,308 & $1,296,288$ & $1,657,775$ & $2,167,540$ \\
\hline Cash & 50,676 & 61,452 & 79,909 & 112,535 \\
\hline Deposits & 881,632 & $1,234,837$ & $1,577,865$ & $2,055,005$ \\
\hline Demand deposits & 278,532 & 365,182 & 473,279 & 596,792 \\
\hline Time deposits & 603,100 & 869,655 & $1,104,586$ & $1,458,212$ \\
\hline CBPPs held by nonbanks & 10,769 & 21,566 & 14,972 & 5,000 \\
\hline Foreign currency deposits & 51,003 & 65,746 & 105,933 & 175,317 \\
\hline \multicolumn{5}{|l|}{ Memorandum items: } \\
\hline Base money & 231,830 & 292,064 & 380,827 & 516,013 \\
\hline M1 & 329,208 & 426,634 & 553,189 & 709,328 \\
\hline Multiplier (M3/base money) & 4.3 & 4.7 & 4.7 & 4.6 \\
\hline Income velocity of M3 & 2.0 & 1.7 & 1.7 & 1.6 \\
\hline \multicolumn{5}{|l|}{ Annual percentage change } \\
\hline NFA & 44.9 & 16.9 & 25.7 & 17.2 \\
\hline NDA & -50.7 & 68.2 & 31.2 & 44.8 \\
\hline Base money & 46.5 & 26.0 & 30.4 & 35.5 \\
\hline M1 & 26.8 & 29.6 & 29.7 & 28.2 \\
\hline M2, excluding foreign currency deposits and CBPPs & 34.6 & 39.0 & 27.9 & 30.7 \\
\hline M3 & 33.6 & 39.2 & 28.6 & 32.0 \\
\hline Credit to private sector and NFPEs in rials & 35.4 & 37.0 & 32.8 & 32.9 \\
\hline Credit to private sector in rials & 38.3 & 41.7 & 35.7 & 34.3 \\
\hline Total claims on private sector & 32.1 & 34.0 & 33.3 & $32 . c$ \\
\hline
\end{tabular}

Sources: Central Bank of Iran; and Fund staff estimates and projections.

1/ The Iranian fiscal year ends on March 20.

2/ Includes some liabilities in foreign currency to residents.

3/ Includes on-lending of the Oil Stabilization Fund resources and claims under letters of credit for trade financing. 
Table 7. Islamic Republic of Iran: Vulnerability Indicators, 2003/04-2007/08 1/

\begin{tabular}{|c|c|c|c|c|c|}
\hline & $2003 / 04$ & $2004 / 05$ & $2005 / 06$ & $2006 / 07$ & $2007 / 08$ \\
\hline \multicolumn{6}{|l|}{ External solvency indicators } \\
\hline Real effective exchange rate (REER) (end of period; percent change) & -2.1 & 1.0 & 6.0 & 3.9 & 3.66 \\
\hline Total public and publicly guaranteed external debt (in billions of U.S. dollars) & 17.1 & 23.1 & 24.8 & 23.2 & 26.16 \\
\hline (In percent of GDP) & 12.7 & 14.3 & 13.2 & 10.4 & 9.16 \\
\hline Short-term external debt (in billions of U.S. dollars) & 4.8 & 10.2 & 10.7 & 9.1 & 9.16 \\
\hline (In percent of GDP) & 3.6 & 6.3 & 5.7 & 4.1 & 3.26 \\
\hline (In percent of exports of goods and services) 2/ & 12.1 & 20.5 & 15.1 & 11.1 & 9.26 \\
\hline External debt service (in percent of exports of goods and services) $2 / 3$ / & 4.5 & 6.5 & 4.4 & 3.9 & 4.36 \\
\hline \multicolumn{6}{|l|}{ External liquidity indicators } \\
\hline Total official reserves (in billions of U.S. dollars) & 24.7 & 33.3 & 46.8 & 60.5 & 81.7 \\
\hline (In months of the following year's imports of goods and services) 2/ & 6.1 & 7.3 & 9.0 & 10.2 & 11.56 \\
\hline (In percent of short-term external debt) & 517 & 326 & 439 & 664 & 8976 \\
\hline Commercial banks net foreign assets (in billions of U.S. dollars) & 4.6 & 12.2 & 18.9 & 19.0 & 20.3 \\
\hline Foreign assets & 6.6 & 27.1 & 29.1 & 28.3 & 33.3 \\
\hline Foreign liabilities 4/ & 2.0 & 15.0 & 10.2 & 9.3 & 13.0 \\
\hline Oil and oil-related exports (in percent of exports of goods) & 80.5 & 82.8 & 83.6 & 82.7 & 84.2 \\
\hline \multicolumn{6}{|l|}{ Public sector solvency indicators } \\
\hline Public and publicly guaranteed debt (in percent of GDP) & 26.5 & 26.3 & 23.7 & 19.7 & 17.26 \\
\hline Oil revenue (in percent of total revenue) & 69.4 & 69.1 & 72.2 & 69.5 & 69.4 \\
\hline \multicolumn{6}{|l|}{ Financial sector indicators } \\
\hline Risk-weighted capital adequacy of banks (in percent) 5/ & 5.7 & 9.8 & 9.9 & 9.1 & $\ldots$ \\
\hline Ratio of nonperforming loans of banks (in percent of total loans) 5/ & 7.4 & 7.7 & 9.9 & 15.7 & $\ldots$ \\
\hline Loan provisions as a percentage of nonperforming loans & 44.6 & 57.9 & 47.1 & $\ldots$ & $\ldots$ \\
\hline Net profit margin of banks to total assets (in percent) & 1.0 & 1.2 & 0.8 & 0.7 & $\ldots$ \\
\hline Net domestic credit (percent change) & 58.9 & 18.5 & 22.3 & 32.1 & 27.1 \\
\hline Private sector credit in local currency (percent change) & 73.8 & 23.0 & 32.1 & 34.0 & 33.3 \\
\hline Net domestic credit (in percent of GDP) & 66.6 & 62.3 & 63.1 & 69.2 & 67.9 \\
\hline \multicolumn{6}{|l|}{ Market assessment/financial market indicators } \\
\hline Stock market price index (percent change; end-of-period) & 124.8 & 6.4 & -21.9 & 5.3 & 2.7 \\
\hline Stock market capitalization (in percent of GDP) & 22.0 & 22.8 & 15.9 & 16.8 & 17.8 \\
\hline Fitch sovereign rating & $\mathrm{B}+$ & BB- & BB- & $\mathrm{B}+$ & $B+7$ \\
\hline
\end{tabular}

Sources: Iranian authorities; and Fund staff estimates.

1/ The Iranian fiscal year ends on March 20.

2/ Excluding interest receipts and payments.

3/ Excluding service of short-term external debt.

4/ Including contingent liabilities under letters of credit.

5/ Islamic banks exhibit important differences in their risk profile and asset classification, which limit international comparability.

6/ Estimate.

7/ As of April 24, 2008, Ficth rating was reaffirmed at B+ and simultaneously withdrawn. 
Table 8. Islamic Republic of Iran: Medium-Term Scenarios, 2006/07-2013/14 1/

\begin{tabular}{|c|c|c|c|c|c|c|c|c|}
\hline & \multirow[b]{2}{*}{$2006 / 07$} & \multirow{2}{*}{$\begin{array}{r}\text { Est. } \\
2007 / 08\end{array}$} & \multicolumn{6}{|c|}{ Projections } \\
\hline & & & $2008 / 09$ & $2009 / 10$ & $2010 / 11$ & $2011 / 12$ & $2012 / 13$ & $2013 / 14$ \\
\hline & \multicolumn{8}{|c|}{ I. Baseline (Current Policies) Scenario } \\
\hline & \multicolumn{8}{|c|}{ (Annual percentage change) } \\
\hline Real GDP at market prices & 5.8 & 6.4 & 5.7 & 5.2 & 4.9 & 4.8 & 4.5 & 4.5 \\
\hline \multirow[t]{2}{*}{$\mathrm{CPI}$ inflation (end of period) } & 15 & 22 & $24-28$ & 21 & 18 & 15 & 15 & 15 \\
\hline & \multicolumn{8}{|c|}{ (In percent of GDP; unless otherwise indicated) } \\
\hline Overall general government balance (cash basis) & 0.7 & 2.8 & 1.9 & 0.8 & -0.4 & -1.1 & -1.7 & -2.6 \\
\hline Non-oil primary balance (commitment basis) & -20.7 & -16.8 & -18.5 & -17.0 & -16.2 & -15.5 & -14.9 & -14.3 \\
\hline Non-oil primary balance in percent of non-oil GDP (commitment basis) & -28.2 & -22.9 & -24.7 & -21.7 & -20.1 & -18.8 & -17.8 & -16.8 \\
\hline Gross debt & 19.7 & 17.2 & 13.9 & 11.9 & 10.3 & 9.2 & 8.1 & 7.9 \\
\hline Gross assets $2 /$ & 15.5 & 17.1 & 15.7 & 14.2 & 12.0 & 9.3 & 6.4 & 3.8 \\
\hline \multirow{2}{*}{$\begin{array}{l}\text { Of which: OSF and Government's foreign exchange deposits } \\
\text { In billions of U.S. dollars }\end{array}$} & 5.2 & 8.1 & 8.1 & 8.1 & 7.1 & 5.5 & 3.5 & 1.6 \\
\hline & 11.7 & 23.0 & 29.7 & 34.8 & 34.7 & 30.1 & 21.4 & 10.9 \\
\hline External current account balance & 9.2 & 10.2 & 9.0 & 5.9 & 3.5 & 1.4 & -0.5 & -2.5 \\
\hline Investment & 32.6 & 31.7 & 31.2 & 31.2 & 30.8 & 30.0 & 29.4 & 28.8 \\
\hline Change in stocks & 6.2 & 6.7 & 6.3 & 6.0 & 5.7 & 5.5 & 5.2 & 5.0 \\
\hline Total fixed capital investment & 26.4 & 25.0 & 24.8 & 25.1 & 25.0 & 24.5 & 24.1 & 23.8 \\
\hline Public & 9.4 & 7.3 & 7.3 & 7.6 & 7.4 & 7.1 & 7.0 & 6.8 \\
\hline Private & 17.0 & 17.7 & 17.5 & 17.5 & 17.7 & 17.4 & 17.2 & 17.0 \\
\hline Gross national savings & 41.8 & 42.0 & 40.2 & 37.1 & 34.3 & 31.4 & 28.8 & 26.3 \\
\hline Public & 10.1 & 10.1 & 9.1 & 8.4 & 7.0 & 6.0 & 5.3 & 4.2 \\
\hline Private & 31.7 & 31.9 & 31.0 & 28.7 & 27.3 & 25.3 & 23.6 & 22.1 \\
\hline Gross official reserves (in billions of U.S. dollars) & 60.5 & 81.7 & 100.2 & 111.7 & 115.1 & 109.2 & 92.7 & 62.0 \\
\hline In months of imports of goods and services & 10.2 & 11.5 & 12.6 & 12.7 & 11.8 & 10.1 & 7.7 & 4.9 \\
\hline \multicolumn{9}{|l|}{ Memorandum items: } \\
\hline \multicolumn{9}{|l|}{ Oil and gas sector } \\
\hline Total oil and gas exports (in billions of U.S. dollars) & 62.5 & 76.9 & 91.0 & 90.6 & 89.5 & 88.9 & 88.8 & 88.9 \\
\hline Average oil export price (in U.S. dollars/barrel) & 57.0 & 72.2 & 86.3 & 84.8 & 83.8 & 83.4 & 83.3 & 83.3 \\
\hline \multirow[t]{3}{*}{ Crude oil production (in millions of barrels/day) } & 4.1 & 4.1 & 4.2 & 4.3 & 4.4 & 4.4 & 4.5 & 4.6 \\
\hline & \multicolumn{8}{|c|}{ II. Active Scenario } \\
\hline & \multicolumn{8}{|c|}{ (Annual percentage change) } \\
\hline Real GDP at market prices & 5.8 & 6.4 & 5.0 & 4.5 & 5.0 & 5.5 & 6.5 & 7.5 \\
\hline \multirow[t]{2}{*}{ CPI inflation (end of period) } & 15 & 22 & 22 & 22 & 14 & 9 & 7 & 7 \\
\hline & \multicolumn{8}{|c|}{ (In percent of GDP; unless otherwise indicated) } \\
\hline Overall general government balance (cash basis) & 0.7 & 2.8 & 5.0 & 5.8 & 4.6 & 3.6 & 2.5 & 1.3 \\
\hline Non-oil primary balance (commitment basis) & -20.7 & -16.8 & -16.0 & -14.7 & -14.7 & -14.6 & -14.6 & -14.4 \\
\hline Non-oil primary balance in percent of non-oil GDP (commitment basis) & -28.2 & -22.9 & -21.3 & -20.6 & -21.0 & -20.2 & -19.6 & -18.8 \\
\hline Gross debt & 19.7 & 17.2 & 14.0 & 10.7 & 9.1 & 8.3 & 7.5 & 7.5 \\
\hline Gross assets $2 /$ & 15.5 & 17.1 & 19.2 & 20.8 & 22.1 & 23.7 & 24.0 & 23.6 \\
\hline Of which: OSF and Government's foreign exchange deposits & 5.2 & 8.1 & 11.3 & 14.7 & 17.1 & 19.4 & 20.4 & 20.6 \\
\hline In billions of U.S. dollars & 11.7 & 23.0 & 41.2 & 70.7 & 98.7 & 123.0 & 142.3 & 159.6 \\
\hline External current account balance & 9.2 & 10.2 & 11.2 & 8.5 & 6.6 & 5.4 & 4.2 & 2.5 \\
\hline Investment & 32.6 & 31.7 & 29.5 & 29.0 & 28.9 & 29.4 & 29.8 & 30.0 \\
\hline Change in stocks & 6.2 & 6.7 & 6.4 & 6.1 & 5.8 & 5.5 & 5.2 & 4.8 \\
\hline Total fixed capital investment & 26.4 & 25.0 & 23.1 & 22.8 & 23.1 & 23.8 & 24.6 & 25.2 \\
\hline Public & 9.4 & 7.3 & 6.3 & 5.8 & 5.6 & 5.8 & 6.1 & 6.2 \\
\hline Private & 17.0 & 17.7 & 16.8 & 17.0 & 17.5 & 18.0 & 18.5 & 19.0 \\
\hline Gross national savings & 41.8 & 42.0 & 40.7 & 37.4 & 35.5 & 34.8 & 33.9 & 32.5 \\
\hline Public & 10.1 & 10.1 & 11.3 & 11.6 & 10.2 & 9.4 & 8.6 & 7.5 \\
\hline Private & 31.7 & 31.9 & 29.4 & 25.8 & 25.3 & 25.4 & 25.3 & 24.9 \\
\hline Gross official reserves (in billions of U.S. dollars) & 60.5 & 81.7 & 113.0 & 150.8 & 186.2 & 218.0 & 244.9 & 260.8 \\
\hline In months of imports of goods and services & 10.2 & 12.3 & 15.4 & 18.4 & 20.7 & 21.8 & 21.9 & 22.1 \\
\hline \multicolumn{9}{|l|}{ Memorandum items: } \\
\hline Oil and gas sector & & & & & & & & \\
\hline Total oil and gas exports (in billions of U.S. dollars) & 62.5 & 76.9 & 93.1 & 96.6 & 97.5 & 97.2 & 97.1 & 96.9 \\
\hline Average oil export price (in U.S. dollars/barrel) & 57.0 & 72.2 & 86.3 & 84.8 & 83.8 & 83.4 & 83.3 & 83.3 \\
\hline Crude oil production (in millions of barrels/day) & 4.1 & 4.1 & 4.2 & 4.3 & 4.4 & 4.5 & 4.5 & 4.6 \\
\hline
\end{tabular}

Sources: Iranian authorities; and Fund staff estimates and projections.

1/ The Iranian fiscal year ends on March 20.

2/ Government deposits with the banking system. 


\title{
INTERNATIONAL MONETARY FUND
}

\author{
ISLAMIC REPUBLIC OF IRAN
}

\section{Article IV Consultation}

\section{Informational Annex}

\author{
Prepared by Middle East and Central Asia Department \\ (In consultation with other Departments) \\ June 19, 2008
}

Contents

Page

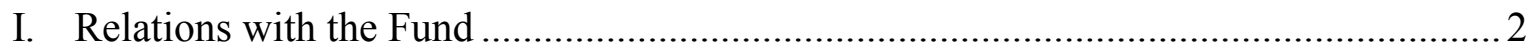

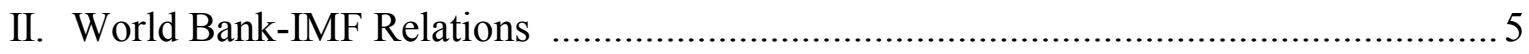

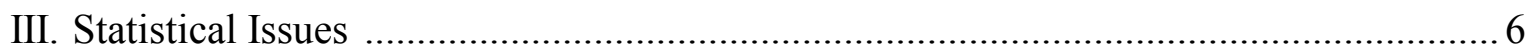




\title{
Annex I. Islamic Republic of Iran: Relations with the Fund
}

\author{
(As of May 31, 2008)
}

I. Membership Status

II. General Resources Account

Quota

Fund holdings of currency

III. SDR Department

Net cumulative allocation

Holdings

IV. Outstanding Purchases and Loans None

V. Financial Arrangements None

VI. Projected Payments to Fund

(SDR Million; based on existing use of resources and present holdings of SDRs)

Principal

Charges/Interest

Total
SDR Million

$1,497.20$

$1,497.20$

$\underline{\text { SDR Million }}$

244.06

282.77
Percent of Quota

100.00

100.00
Percent of Allocation

100.00

115.86

\begin{tabular}{lcccc}
\multicolumn{5}{c}{ Forthcoming } \\
\hline$\underline{2008}$ & $\underline{2009}$ & $\underline{2010}$ & $\underline{2011}$ & $\underline{2012}$
\end{tabular}

$\begin{array}{llll}\underline{0.02} & \underline{0.02} & \underline{0.02} & \underline{0.02} \\ 0.02 & 0.02 & 0.02\end{array}$

\section{Nonfinancial Relations}

\section{Exchange System}

The exchange rate is determined in the interbank foreign exchange market. Effective

December 1, 2007, the exchange rate regime was reclassified from the category of a de facto fixed peg to a composite to the category of a de facto crawling peg to a composite.

With effect from September 6, 2004, the Islamic Republic of Iran accepted the obligations under Article VIII, Sections 2, 3, and 4 of the Fund's Articles of Agreement. Iran maintains 
one exchange restriction and two multiple currency practices subject to Fund jurisdiction under Article VIII, Sections 2(a) and 3.

a. The exchange restriction arises from limitations on the transferability of rial profits from certain investments under the Foreign Investment Promotion and Protection Act and from limitations on other investment-related current international payments under this act.

b. The multiple currency practices arise from:

Budget subsidies for foreign exchange purchases in connection with payments of certain letters of credit opened prior to March 21, 2002 under the previous multiple exchange rate system; and

Obligations of entities that had received allocations of foreign exchange at subsidized "allocated rates" under the previous multiple exchange rate system to surrender unused allocations to the Central Bank of Iran at the allocation rate.

\section{Last Article IV Consultation}

The last Article IV consultation was concluded by the Executive Board on February 23, 2007.

\section{Technical Assistance}

Since FY 2003, Iran received the following technical assistance:

\section{FAD}

FY 2004-Tax administration and VAT

\section{LEG}

FY 2007-Anti-Money Laundering/Combating Financing of Terrorism regulations

\section{MCM/MFD}

FY 2003 - Banking Supervision, short visits by MFD expert

FY 2003 - Exchange System, reviewed the foreign exchange system after the exchange rate unification; explored issues of capital account liberalization

FY 2004 - Article VIII acceptance mission

FY 2007 - Banking regulation and supervision

FY 2008 - Currency reform 
FY 2009 - Monetary policy modeling

\section{STA}

FY 2003 - Multisector mission, assessed current data dissemination practices against the requirements of the SDDS and provided technical assistance on ways to improve the compilation of the macroeconomic statistics that would facilitate SDDS subscription

FY 2004 - Follow-up mission on progress in meeting SDDS requirements

FY 2005 - Follow-up mission on progress in meeting SDDS requirements in balance of payments and international investment position 


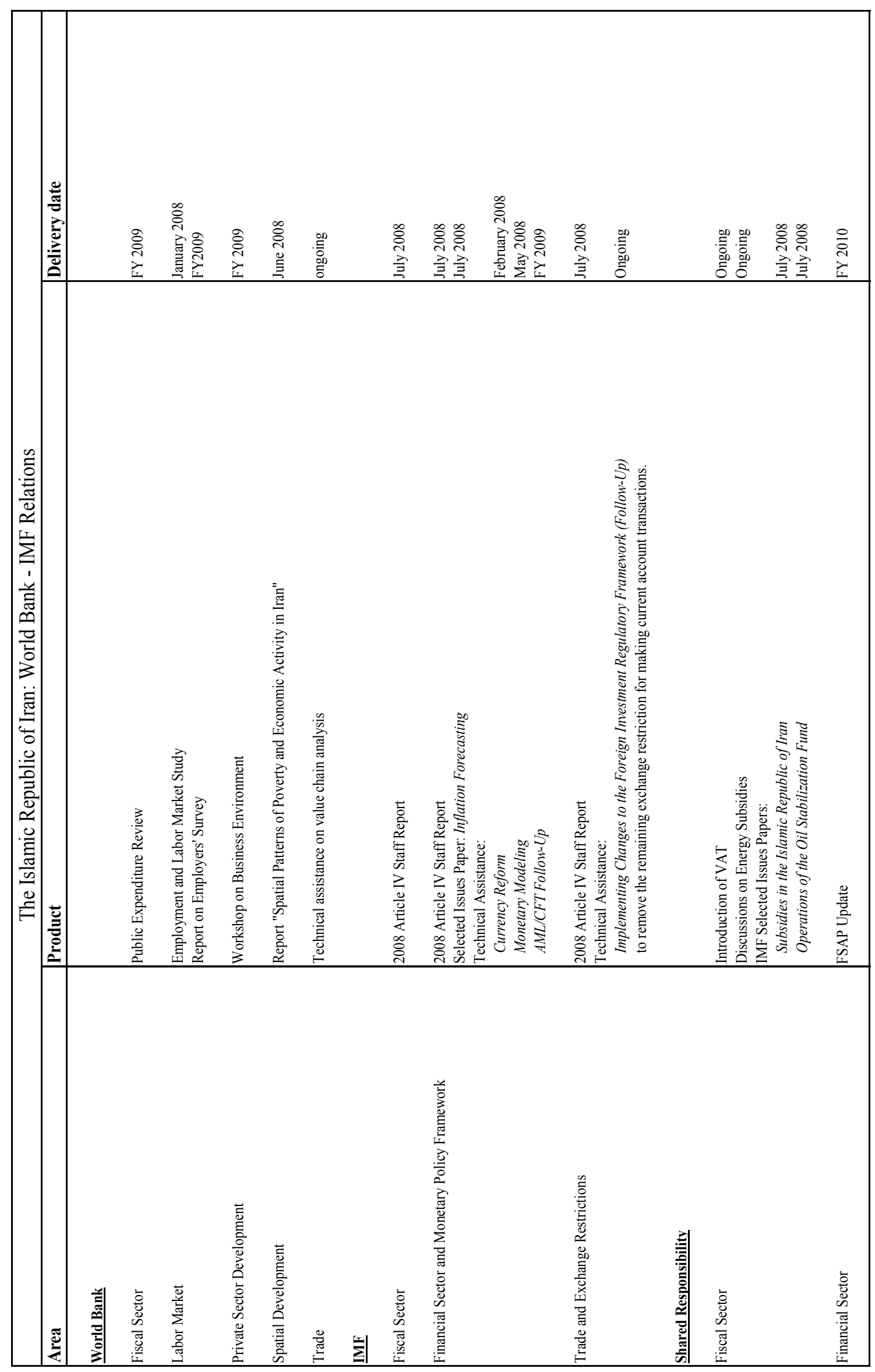




\section{Annex III. Islamic Republic of Iran: Statistical Issues}

Data reporting to the Fund is broadly adequate for effective surveillance, but the remaining weaknesses need to be addressed. The Central Bank of Iran (CBI) disseminates key statistical aggregates in its quarterly Economic Trends, also available at $\leq$ http://www.cbi.ir/e/ $>$. Recent improvements in data dissemination on the CBI website are welcome. However, there is a need to expand the coverage of the central government operations, and to improve the timeliness of financial sector vulnerability indicators. Since 2002, the Fund's Statistics Department has assisted the authorities in their efforts to subscribe to the Special Data Dissemination Standard (SDDS), which is still pending.

\section{Real sector statistics}

- National accounts statistics are reasonably sound. Improvements have been made in the coverage of the informal economy. However, there is scope for further progress, especially in the coverage of small-scale industries and services. Also, the CBI and the Statistical Council of Iran (SCI) have undertaken to review and unify their respective GDP estimates.

- $\quad$ Price statistics are sound and released in a timely manner. The official labor market statistics are released by the SCI, and are based on the definitions recommended by the International Labor Organization (ILO). The data are based on an urban and rural population sample of about 100,000 households, and the threshold for considering a person employed is two days a week. Labor market statistics, however, could benefit from further improvement, particularly with regard to employment and wage data.

\section{Government finance statistics}

- $\quad$ The data are compiled in accordance with the Government Finance Statistics Manual, 2001 (GFSM 2001) for the core central government operations. Starting in 2003/04, the fiscal data include implicit energy subsidies.

- Data on central government operations, including the budgetary central government, the Oil Stabilization Fund (OSF), and the Social Security Organization (SSO) are reported to the Fund. Consolidated data on the budgetary central government and SSO, and some elements of the OSF operations are disseminated.

- $\quad$ There is a need to expand the coverage of central government to include four pension funds and five procurement and distribution centers.

- $\quad$ The submission for the Government Finance Statistics Yearbook includes data for general and local governments starting in 2006.

- $\quad$ The existing cash-based government accounting system should be upgraded to enable recording of expenditures at the pre-payment stage. 
- $\quad$ The discrepancy between fiscal and monetary data on deficit financing has often been relatively large, partly due to foreign currency valuation problems. There is a need to develop a comprehensive database on domestic public debt, with a breakdown by domestic creditor.

- $\quad$ The Bonyad-e-Mostazafan va Janbazan (BMJ, Foundation of the Oppressed and Injured) could be considered a holding company and classified in the nonfinancial public corporations sector.

\section{Monetary statistics}

- Monthly monetary data are reported to STA on a regular basis for publication in IFS, but timeliness has been lagging.

- Compilation of monetary statistics diverges from international standards in the application of the residency criterion and in sectorization and classification. The authorities are undertaking improvements in each of these areas, in line with the recommendations of two STA missions in 2001 and 2003.

- $\quad$ The measure of broad money employed by the CBI does not include deposits of public nonfinancial corporations, local governments, or foreign-currency deposits of residents.

- $\quad$ The authorities are yet to submit test data in the format of Standarized Report Forms (SRFs) developed by STA for reporting monetary data in line with the methodology of the Monetary and Financial Statistics Manual.

\section{External sector data}

- The accounting system for foreign exchange receipts and payments of the CBI and banks is being implemented in line with the methodological guidelines of the Fund's Balance of Payments Manual, fifth edition (BPM5). This will allow compilation of balance of payments statistics on a quarterly basis. Annual balance of payments data up to 2000 were reported to STA for publication in BOPSY and IFS.

- Some data on the international investment position are compiled and reported to Fund staff. These data include gross international reserves, commercial banks' assets, OSF assets, and debt liabilities. However, only data on public and publicly guaranteed debt and net international reserves are disseminated. Moreover, the debt classifications do not fully accord with the guidelines of the External Debt Guide. The data template on international reserves and foreign currency liquidity is not compiled. 


\section{Table of Common Indicators Required for Surveillance (As of May 28, 2008)}

\begin{tabular}{|c|c|c|c|c|c|}
\hline & $\begin{array}{c}\text { Date of } \\
\text { latest } \\
\text { observation }\end{array}$ & $\begin{array}{l}\text { Date } \\
\text { received }\end{array}$ & $\begin{array}{c}\text { Frequency } \\
\text { of } \\
\text { Data }^{6}\end{array}$ & $\begin{array}{l}\text { Frequency } \\
\text { of } \\
\text { Reporting }^{6}\end{array}$ & $\begin{array}{l}\text { Frequency } \\
\text { of } \\
\text { Publication }\end{array}$ \\
\hline Exchange Rates & $\begin{array}{l}\text { May 28, } \\
2008\end{array}$ & $\begin{array}{l}\text { May 28, } \\
2008\end{array}$ & $\mathrm{D}$ & $\mathrm{D}$ & $\mathrm{D}$ \\
\hline \multicolumn{6}{|l|}{$\begin{array}{l}\text { International Reserve Assets and } \\
\text { Reserve Liabilities of the Monetary } \\
\text { Authorities }{ }^{1}\end{array}$} \\
\hline International Investment Position & Dec. 2007 & May 2008 & Q & Q & Q \\
\hline Reserve/Base Money & Mar. 2008 & May 2008 & M & M & Q \\
\hline Broad Money & Mar. 2008 & May 2008 & M & M & Q \\
\hline Central Bank Balance Sheet & Mar. 2008 & May 2008 & M & M & Q \\
\hline $\begin{array}{l}\text { Consolidated Balance Sheet of the } \\
\text { Banking System }\end{array}$ & Mar. 2008 & May 2008 & M & M & Q \\
\hline Interest Rates ${ }^{2}$ & Mar 2008 & May 2008 & M & M & Q \\
\hline Consumer Price Index & Apr. 2008 & May 2008 & M & M & M \\
\hline $\begin{array}{l}\text { Revenue, Expenditure, Balance and } \\
\text { Composition of Financing }{ }^{3} \text {-Central } \\
\text { Government }\end{array}$ & $\begin{array}{l}\text { 2007/08 } \\
\text { (March 20, } \\
2008)\end{array}$ & May 2008 & A & A & $A$ \\
\hline $\begin{array}{l}\text { Revenue, Expenditure, Balance and } \\
\text { Composition of Financing }{ }^{3} \text {-General } \\
\text { Government }\end{array}$ & $\begin{array}{l}2006 / 07 \\
(\text { March 20, } \\
2007)\end{array}$ & 2007 & A & $A$ & $A$ \\
\hline $\begin{array}{l}\text { Stocks of Central Government and } \\
\text { Central Government-Guaranteed Debt }\end{array}$ & Dec. 2007 & May 2008 & $A$ & $A$ & $A$ \\
\hline External Current Account Balance & Dec. 2007 & May 2008 & $M$ & $Q$ & $Q$ \\
\hline $\begin{array}{l}\text { Exports and Imports of Goods and } \\
\text { Services }\end{array}$ & Dec. 2007 & May 2008 & M & $Q$ & $Q$ \\
\hline GDP/GNP & $\begin{array}{l}\text { First half } \\
2007 / 08\end{array}$ & May 2008 & Q & Q & Q \\
\hline Gross External Debt & Dec. 2007 & May 2008 & $M$ & $Q$ & $Q$ \\
\hline
\end{tabular}

1/ Includes reserve assets pledged or otherwise encumbered as well as net derivative positions.

2/ Both market-based and officially determined, including discount rates, money market rates, rates on treasury bills, notes and bonds.

3/Foreign, domestic bank, and domestic nonbank financing.

4/The general government consists of the central government (budgetary funds, extra budgetary funds, and social security funds) and state and local governments.

$5 /$ Including currency and maturity composition.

6/ Daily (D), weekly (W), monthly (M), quarterly (Q), annually (A), irregular (I), and not available (NA). 


\section{INTERNATIONAL MONETARY FUND}

EXTERNAL

Public Information Notice (PIN) No. 08/86

FOR IMMEDIATE RELEASE

July 18,2008
International Monetary Fund $70019^{\text {th }}$ Street, NW

Washington, D. C. 20431 USA

\section{IMF Executive Board Concludes 2008 Article IV Consultation with the Islamic Republic of Iran}

On July 14, 2008, the Executive Board of the International Monetary Fund (IMF) concluded the Article IV consultation with the Islamic Republic of Iran. ${ }^{1}$

\section{Background}

Iran's growth performance has been robust in recent years, benefiting from high oil prices, regional growth, and a strong policy stimulus. Real GDP growth is estimated to have increased from 6.2 percent in 2006/07 (Iranian fiscal year starts on March 21) to 6.6 percent in 2007/08, with real non-oil GDP growth estimated at 7.3 percent, on account of buoyant domestic demand and increased government support for the priority sectors. Real oil GDP is estimated to have increased by about 1 percent, as production capacity was constrained by insufficient investment. Unemployment declined slightly to 9.8 percent in the year to December 2007.

The external position is estimated to have strengthened significantly in $2007 / 08$. The current account surplus rose to 10 percent of GDP in 2007/08, from 9.2 percent in 2006/07. Gross official reserves reached $\$ 82$ billion (12 months of imports) and the external debt is estimated to have declined to 9 percent of GDP by end-March 2008.

\footnotetext{
${ }^{1}$ Under Article IV of the IMF's Articles of Agreement, the IMF holds bilateral discussions with members, usually every year. A staff team visits the country, collects economic and financial information, and discusses with officials the country's economic developments and policies. On return to headquarters, the staff prepares a report, which forms the basis for discussion by the Executive Board. At the conclusion of the discussion, the Managing Director, as Chairman of the Board, summarizes the views of Executive Directors, and this summary is transmitted to the country's authorities.
} 
Inflation rose to 24.2 percent in April 2008, from 16.8 percent in April 2007. A significant increase in inflation excluding food and energy suggests strong underlying domestic demand pressures. Higher import prices constituted an additional cost-push factor.

While the fiscal stimulus was reduced somewhat in 2007/08, the budget continued to provide impetus to domestic demand growth. The non-oil primary fiscal deficit declined to 17 percent of GDP in 2007/08 from 21 percent in 2006/07, on account of the rationing of subsidized gasoline, a reduction in nonwage current outlays, slower growth of capital expenditure, and lower OSF lending. However, budgetary expenditure increased by almost 15 percent in 2007/08 in addition to a cumulative rise of more than 40 percent during 2005/06-2006/07.

Broad money growth remained relatively high in 2007/08. Reduced banking rates of return, pressures on commercial banks to expand credit, and unsterilized purchases of foreign exchange by the Central Bank of Iran contributed to this outcome. While the banking supervision legislation has been improved, some state-owned banks were still undercapitalized as of end-March 2008. Moreover, the deepening of financial intermediation has slowed down in response to negative banking rates of return in real terms.

Progress in structural reforms has been mixed. The increase in energy subsidies has been contained through the rationing of gasoline at increased prices, the VAT is close to implementation, and tax administration has been modernized. Moreover, following the 2006 reinterpretation of Article 44 of the Constitution, the divestment process has gathered pace. However, given the lack of large private investors, many government-owned entities have been acquired through non-cash or deferred settlements by quasi-public sector institutions. Furthermore, remaining weaknesses in the business environment hinder private sector development and employment creation.

The growth and external prospects for 2008/09 are good, but on current policies inflation is expected to remain high. Real GDP growth is projected at 5.7 percent in 2008/09. Notwithstanding buoyant domestic demand, the external current account surplus would remain broadly unchanged at 9-10 percent of GDP, as oil prices are assumed to remain well above their 2007/08 level. The non-oil primary fiscal deficit is projected to increase to 18.5 percent of GDP in 2008/09, from 17 percent in $2007 / 08$. This, together with the maintenance of the current monetary policy stance, will most likely cause inflation to remain at about 25 percent in the near term. 


\section{Executive Board Assessment}

Executive Directors welcomed Iran's continued strong growth performance, particularly in the non-oil sector. The country's external position had strengthened further, reflecting the impact of higher oil prices. They noted, however, that inflation is rising, largely due to the expansionary policy stance and also, in part, to higher import prices. Looking forward, Directors encouraged the authorities to act promptly to prevent inflationary expectations from becoming entrenched, against a background of a generally favorable short-term growth outlook.

Directors viewed that strengthening the fiscal position in 2008/09 will help to ease demand pressures and limit the liquidity impact of fiscal operations. They welcomed the authorities' intention to contain expenditure below the budget level, and observed that there is room for additional fiscal measures, particularly in the area of energy subsidies.

Directors emphasized that, in the medium-term, further fiscal consolidation will be needed to reduce inflationary pressures, prevent an erosion of external competitiveness, and reduce the economy's vulnerability to a possible decline in oil prices. They agreed that adopting a rolling medium-term fiscal framework and focusing the operations of the Oil Stabilization Fund (OSF) on its stabilization objective would facilitate fiscal management in the face of oil price volatility.

Directors welcomed the authorities' plans for far-reaching fiscal reforms and looked forward to their steadfast implementation. In particular, they supported the intention to replace the current subsidy program by targeted cash transfers to the poor.

Directors encouraged the authorities to move ahead with measures to improve tax administration and streamline budgetary personnel expenditure.

Directors emphasized that the recent rise in inflation calls for monetary policy to be tightened. They expressed doubt about the effectiveness of moral suasion and interbank market operations in mopping up excess liquidity to slow money growth. They encouraged a significant increase in banking rates of return as a more effective way to tighten monetary conditions and support financial intermediation. Directors generally recommended increased reliance on market-based instruments in monetary operations. Most Directors were also of the view that greater exchange rate flexibility would enhance the effectiveness of monetary policy.

Directors observed that strengthening the operational independence of the central bank and establishing low inflation as its main objective will increase the effectiveness of monetary policy and anchor inflationary expectations. They looked forward to the resumption of work on a new central bank law. 
Directors noted the importance of a strengthened and deregulated banking system, welcomed recent steps to improve banking supervision and the authorities' plans to recapitalize state-owned banks. These measures would be enhanced by accompanying improvements in the central bank's capacity to enforce prudential norms and a gradual deregulation of banking rates of return and credit allocation.

Directors looked forward to the prompt completion of ongoing work in the area of anti-money laundering legislation through the adoption of appropriate implementing regulations, and noted the authorities' commitment to establishing an appropriate framework for combating financing of terrorism. They welcomed the authorities' intention to continue cooperating with international financial institutions on these issues.

Directors noted that achieving the authorities' objectives of improving competitiveness and boosting economic growth and employment creation would require an intensification of structural reforms aimed at stimulating private sector development. In particular, they underscored the need to gear the divestment process to private investors and improve the business climate in close cooperation with the World Bank.

Directors also encouraged the authorities to take the necessary steps to eliminate the exchange restriction related to certain investments under the foreign investment law.

Directors welcomed the recent improvements in data dissemination and the authorities' intention to provide more information on Oil Stabilization Fund operations to the public. They observed that further efforts were needed to broaden the coverage of the central government operations and the timeliness of financial sector vulnerability indicators.

Public Information Notices (PINs) form part of the IMF's efforts to promote transparency of the IMF's views and analysis of economic developments and policies. With the consent of the country (or countries) concerned, PINs are issued after Executive Board discussions of Article IV consultations with member countries, of its surveillance of developments at the regional level, of post-program monitoring, and of ex post assessments of member countries with longer-term program engagements. PINs are also issued after Executive Board discussions of general policy matters, unless otherwise decided by the Executive Board in a particular case. 


\begin{tabular}{|l|r|r|r|r|}
\hline \multicolumn{3}{|c|}{ Islamic Republic of Iran: Selected Economic Indicators, 2005/06-2007/08 } \\
\hline & & & & \\
\hline & $2005 / 06$ & $2006 / 07$ & $2007 / 08$ & \\
\hline Real GDP growth (factor cost; percentage change) & & & & \\
\hline CPI inflation (period average; percentage change) & 5.7 & 6.2 & 6.6 & $1 /$ \\
\hline CPI inflation (end of period; percentage change) & 10.4 & 11.9 & 18.4 & \\
\hline Unemployment rate (in percent) & 10.2 & 15.3 & 22.5 & \\
\hline Central government balance (in percent of GDP) & 12.1 & 12.1 & $\ldots$ & \\
\hline Broad money growth (percentage change) & 1.7 & 0.0 & 3.8 & $1 /$ \\
\hline Current account balance (in percent of GDP) & 33.6 & 39.2 & 28.6 & \\
\hline Overall external balance (in percent of GDP) & 8.8 & 9.2 & 10.2 & $1 /$ \\
\hline Gross international reserves (in billions of U.S. dollars) & 7.2 & 6.1 & 7.4 & $1 /$ \\
\hline Public and publicly guaranteed external debt (in percent of GDP) & 46.8 & 60.5 & 81.7 & \\
\hline Exchange rate (period average; rials per U.S. dollar) & 13.2 & 10.4 & 9.1 & $1 /$ \\
\hline & 9,026 & 9,202 & 9,285 & \\
\hline $\begin{array}{l}\text { Sources: Iranian authorities; and IMF staff estimates. } \\
\text { 1/ Estimate. }\end{array}$ & & & & \\
\hline
\end{tabular}




\section{Statement by Jafar Mojarrad, Executive Director for the Islamic Republic of Iran July 14, 2008}

1. My authorities are thankful to the staff for the constructive policy discussions and the high-quality reports, which provide useful insights into their policy challenges. As in the past, the economic debate in Iran will continue to benefit from the IMF analysis and policy advice, most notably the views expressed by Executive Directors.

2. The authorities have continued to pursue their economic and social objectives under the Fourth Five-Year Development Plan (FFYDP, 2004-09), now in the final stage of implementation, and the 20-Year Vision Plan. The policy agenda has remained focused on growth and employment, development of the non-oil sector, encouragement of the private sector, and equitable distribution of resources in order to reduce regional and social disparities. These objectives have been pursued with determination in an environment that could be characterized as mixed. On the one hand, high oil export prices have provided the necessary resources for financing investment in infrastructure and expanding production capacity while maintaining an adequate level of social protection for the needy; on the other, intensified international pressures and new sanctions have hindered foreign participation in the oil sector, raised the cost of doing business with Iran, weakened the smooth functioning of international banking payments and clearance, and complicated the task of macroeconomic management.

\section{Developments in 2007/08}

3. In 2007/08, growth was high and broad-based, and unemployment declined despite the rapid growth of the labor force. Real GDP is estimated to have expanded by 6.6 percent, supported by sustained domestic demand growth. The non-oil sector grew by 7.3 percent, continuing a streak of high output growth since $2005 / 06$, driven by strong performance in the manufacturing and service sectors. The oil sector, however, recorded a moderate growth due to insufficient foreign investment. The external position strengthened further in 2007/08, with the current account surplus reaching an all-time high of 10 percent of GDP on the account of increased oil exports and good performance of non-oil exports, the latter mainly reflecting improved competitiveness. Gross official reserves, including those of the Oil Stabilization Fund, rose to the equivalent of 12 months of imports.

4. While these developments attest to the resilience of the economy, the rise of inflation is a source of concern. My authorities believe that inflationary pressures have been driven by a combination of factors, including strong domestic demand growth, high import prices, and international pressures and sanctions. Efforts were made in 2007/08 to rebalance macroeconomic policies toward containing inflation, but these have proved insufficient to achieve the desired objective and would need to be strengthened in the period ahead. 
5. Fiscal policy was tightened in $2007 / 08$. The non-oil primary deficit declined by about 4 percentage points of GDP, compared to 2006/07, and the non-oil deficit as a ratio of non-oil GDP declined by about 5 percent. The brunt of the fiscal consolidation fell on capital expenditure, which was reduced in real terms by 14 percent.

6. The fiscal adjustment provided room for monetary policy tightening to reign in inflation. The authorities increased the amount of open market operations on CBPPs to absorb liquidity, but this proved insufficient to offset redemptions, given the negative real rates of return. However, the effectiveness of monetary policy was constrained by several factors, including the government-mandated reduction in banks' rates of return to stimulate private sector activity, liquidity injection by the OSF, and unsterilized net purchases of foreign exchange by the Central Bank of Iran (CBI). Although in 2007/08 the growth of broad money (M3) was reduced compared to the previous year, narrow money (M1) grew by about 30 percent (or about the same rate as in 2006/07), and inflation started to move up.

7. The exchange regime has continued to operate smoothly, and confidence in the rial has remained intact. The authorities have allowed for some depreciation in the nominal rate to compensate for the inflation differential vis-à-vis Iran's trading partners and protect the competitiveness of the non-oil sector. This policy, however, may conflict with the disinflation objective and will be reviewed in light of the findings of a comprehensive study on the benefits and costs of allowing the rial to appreciate in nominal terms. The authorities are of the view that Iran's exchange rate regime is a managed float with respect to a basket of currencies, since they do not target any particular rate. They remain open to further discussion of this issue with staff. With regard to the exchange restrictions in connection with the transferability of rial profits from certain investments under the foreign investment law, the Ministry of Finance, after consultation with the IMF Legal Department (LEG), has sent the draft amendments, which had been revised based on the IMF comments, to the cabinet for approval.

8. In the financial sector, domestic banks performed relatively well, even though the international sanctions affected their relations with foreign partners. The private banks continued to expand and have increased their market share to about 20 percent. In addition, three state-owned banks were recapitalized and there are plans to privatize five mid-sized state-owned banks. Regulations were set to allow foreign banks, or their branches, to be established in the mainland. In this regard, the first branch of a European bank was recently inaugurated in Tehran. The interbank market became recently operational, and the authorities have requested technical assistance to enhance its operation. In addition, the CBI approved new regulations on asset classification, provisioning, and banks' investment, and has issued new guidelines on liquidity management, internal controls, and corporate governance. Moreover, bank supervision was strengthened significantly to bring it close to international standards. Recent developments in the Iranian stock market are also promising, and stock exchange indices have been on an upward trend since April 2008. 
9. The passage of the AML law, which became effective in January 2008, further strengthened the AML/CFT enforcement framework, and the by-laws and implementing regulations are under preparation based on Fund TA recommendations. The authorities look forward to receiving an IMF technical assistance mission to examine progress in developing the AML/CFT framework and to provide further recommendations.

10. Progress has been made in key structural reforms aimed at raising growth potential and enhancing the role of the private sector. In this regard, privatization has shown momentum, with private investors purchasing shares during the last two months to the tune of 2 billion Euros in companies operating in steel, shipping, copper, and petrochemicals. Preparatory work of a comprehensive subsidy reform also progressed. In the meantime, in order to reduce the budget cost of subsidies on imported fuel products, rationing of gasoline was introduced, which, consequently, has helped reduce consumption and imports. Fiscal reform focused on revenue mobilization, including upgrading tax collection agencies with new IT and accelerating the implementation of the VAT.

\section{Policies in 2008/09}

11. Continued international pressures will impede expansion of oil production capacity, while the drought will affect agricultural output and possibly weigh down on growth in the non-oil sector. Against this background, macroeconomic policies will be geared toward reducing inflation, while the pace of structural reforms will be accelerated to support growth and employment and achieve the FFYDP's targets. In the fiscal area, efforts will focus on mobilization of non-oil revenue to offset the temporary revenue loss that could result from the switch from the sales tax to the VAT. Based on a recent government circular to line ministries, capital expenditure will be reduced by 30 percent, while current spending, excluding on lending by OSF, will be slightly above the previous year's level as a ratio of GDP. As a result, my authorities expect the fiscal outcome to be stronger than envisaged under the approved 2008/09 budget. They also stand ready to make further expenditure cuts in the course of the fiscal year, if necessary.

12. The CBI and the government's Supreme Council for Economic Management and Planning are working closely to formulate comprehensive policy recommendations to reduce inflation. In the meantime, the CBI will seek to maintain the rates of return at their current level, and will use moral suasion to contain the rapid credit growth. Also, the CBI will continue to tighten its lending to banks through the overdraft facility to mop up excess liquidity. In parallel and in light of the findings of the study mentioned above, exchange rate policy will be made more consistent with the need to achieve disinflation.

13. In the financial sector, the authorities plan to inject the equivalent of about $\$ 10$ billion of additional capital into the remaining under-capitalized state-owned banks by converting OSF deposits into equity. To encourage private sector participation in the financial sector, the government will divest its equity holding in two mid-sized banks. 


\section{Medium-term reforms}

14. The authorities' medium-term strategy involves important, but challenging reforms that could have far-reaching positive effects on the economy, the most important of which is the reform of the subsidy system, together with the establishment of a more efficient and better-targeted social safety net. In its well-crafted SIP, staff highlight in detail the high cost and inefficiency of the current subsidy system and its harmful effects on the economy and the environment. By and large, the authorities agree with these conclusions, and are working on a comprehensive package of reforms to be implemented in the second half of the current Iranian year. The main objective is to replace the present subsidy system with cash transfers to households, to be modulated by income category based on a census on households' economic situation.

15. The pace of privatization will be accelerated. Following the reinterpretation of Article 44 of the Constitution, about 80 percent of state-owned enterprises in the various economic sectors, including oil and gas, petrochemicals, banks and insurances, and telecommunications will be privatized by 2010 . To facilitate the process, the authorities intend to clarify the legal framework for the transfer of shares to the beneficiaries, provide assistance to the public enterprises that will offer their shares on the Tehran Stock Exchange, and restructure the companies that do not meet the requirements for divestiture. The authorities look forward to cooperating with the World Bank to improve the financial operations and management of public enterprises and enhance private sector participation in the economy.

16. In the fiscal area, plans are underway to streamline the public administration to reduce the wage bill and broaden the tax base through revenue administration measures. The authorities are also considering moving from the current system of five-year fiscal planning to a rolling medium-term fiscal framework.

\section{Other issues}

17. My authorities attach high value to their participation in the multilateral cooperation system. In particular, despite the fact that Iranian law criminalizing money laundering and the financing of terrorism has been in place since 1986, the authorities worked diligently to obtain parliament approval of the AML bill, which became effective in January 2008. Soon thereafter, they moved to accelerate the preparation of the by-laws and implementing regulations, which are key to enhancing the AML/CFT framework. As explained last year, under Iran's legal system, laws are drafted in a summary form, leaving the technical and procedural details to be clarified in by-laws and implementing regulations. The authorities look forward to discussing these issues with the forthcoming IMF AML/CFT mission and to benefit from its recommendations. Also, in the same spirit, the authorities have applied for Iran's membership in the FATF, and have asked that their application be placed on the fast 
track agenda. Moreover, they have actively participated in the international community's efforts to support the reconstruction of Afghanistan and its economic developments.

18. With regard to the recent decision by the governments of a few EU countries to freeze the assets of Bank Melli's subsidiary and branches in their respective jurisdictions, my authorities believe that this decision is politically motivated and is not justified on regulatory grounds. This subsidiary and branches have never been found in violation of the regulations of the host countries.

19. More generally, my authorities believe that the international payments system should be insulated from the vagaries of political differences among member countries. Political disputes between countries come and go, but the casualty should not be the credibility and integrity of the international payments system. The IMF, as the guardian of this system, has a role to play in this regard, and my authorities have full confidence in its capacity to do so. 